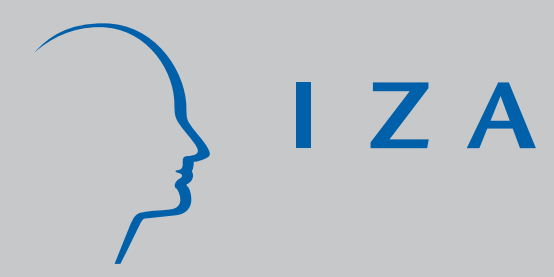

IZA DP No. 1734

Alternative Composite Lisbon

Development Strategy Indices

Almas Heshmati

Jong-Eun Oh

September 2005 


\title{
Alternative Composite Lisbon Development Strategy Indices
}

\author{
Jong-Eun Oh \\ TEPP, Seoul National University \\ Almas Heshmati \\ TEPP, Seoul National University \\ and IZA Bonn \\ Discussion Paper No. 1734 \\ September 2005
}

\author{
IZA \\ P.O. Box 7240 \\ 53072 Bonn \\ Germany \\ Phone: +49-228-3894-0 \\ Fax: +49-228-3894-180 \\ Email: iza@iza.org
}

\begin{abstract}
Any opinions expressed here are those of the author(s) and not those of the institute. Research disseminated by IZA may include views on policy, but the institute itself takes no institutional policy positions.

The Institute for the Study of Labor (IZA) in Bonn is a local and virtual international research center and a place of communication between science, politics and business. IZA is an independent nonprofit company supported by Deutsche Post World Net. The center is associated with the University of Bonn and offers a stimulating research environment through its research networks, research support, and visitors and doctoral programs. IZA engages in (i) original and internationally competitive research in all fields of labor economics, (ii) development of policy concepts, and (iii) dissemination of research results and concepts to the interested public.
\end{abstract}

IZA Discussion Papers often represent preliminary work and are circulated to encourage discussion. Citation of such a paper should account for its provisional character. A revised version may be available directly from the author. 


\section{ABSTRACT}

\section{Alternative Composite Lisbon Development Strategy Indices*}

This study addresses the measurement of two composite Lisbon strategy indices that quantifies the level and patterns of development for ranking countries. The first index is nonparametric labelled as Lisbon strategy index (LSI). It is composed of six components: general economics, employment, innovation research, economic reform, social cohesion and environment, each generated from a number of Lisbon indicators. LSI by reducing the complexity of the set of indicators, it makes the ranking procedures quite simple. The second and parametric index is based on principal component analysis. Despite the difference in the ranking by the two indices, it is shown that the United States outperformed most EU-member states. Our investigations also show evidence of significant dynamic changes taking place, as the countries of the Union struggle to achieve the Lisbon goals. The necessity of a real reform agenda in several old and new members and candidate countries emerges from our analysis.

JEL Classification: O10, C43, F15, O57

Keywords: economic development, economic integration, composite index, Lisbon Agenda

Corresponding author:

Almas Heshmati

Techno-Economics \& Policy Program

College of Engineering

Seoul National University

San 56-1, Shillim-dong, Kwanak-gu

Seoul 151-742

Korea

Email: heshmati@snu.ac.kr

\footnotetext{
* The authors would like to thank Arno Tausch for his comments and suggestions on an earlier version of this paper.
} 


\section{INTRODUCTION}

Development of performance and efficiency indicators related to national economic environment is a very important process to measure and to verify the international economic competitiveness and to evaluate the policy of countries. For this purpose the EU launched a comprehensive set of targets which is called "Lisbon strategy". At the European Council of March 2000 in Lisbon, they announced the targets for EU to become the most competitive and dynamic knowledge-based economy in the world, capable of sustainable economic growth with more and better jobs and greater social cohesion.

There are 14 main structural Lisbon agenda indicators. These indicators play an important role in European policy making and in monitoring EU economic and social policy and its development. The lists of indicators are perhaps the most important checklists for individual government's success or failure in Europe today. Despite their limitations, but because of its relatively good coverage, they are frequently present in the public political as well as scientific debate. 1

In general it is assumed that a good performance on one indicator is causally linked to a good performance on the other indicators. But a recent study by the European Commission (2005) warns that it is very difficult to quantify the impact of the reforms because of the heterogeneity of individual reform measures, time lags in reform implementation and complementarities and trade-offs between reforms across countries. The Commission classifies the Lisbon reforms into five reform categories2.

The study by the European Commission underlines that product and labour market reforms alone in the second half of the 1990s resulted in an increase in annual GDP growth of almost $0.5 \%$. When also taking into account the potential contribution of increased investment in knowledge, the increase in EU potential annual growth could reach $0.75 \%$. Over a ten-year period, this would imply an increase in the GDP level of up to 7 or $8 \%$. In addition it is emphasized that costs of not achieving a better environment may be felt in a reduced quality of life, negative health impacts, lost economic opportunities, and economic costs as a result of a poor environment. The report points to the need for further research to establish what policies are needed to maximize the benefits of Lisbon while minimizing the adjustment and negative costs.

In this study we present results from the computation of two composite indices corresponding to the Lisbon structural development strategy. Without a proper methodological handling of the statistical observations provided by Eurostat on the Lisbon process, little progress will be made in establishing the state of performance of

1 List of Lisbon indicators include: GDP per capita; Labour productivity; Employment rate; Employment rate of older workers; Educational attainment; Research and Development expenditure; Business investment; Comparative price levels; At risk-of-poverty rate; Long-term unemployment rate; Dispersion of regional employment rates; Greenhouse gas emissions; Energy intensity; and Volume of freight transport. A high level of the first 7 indicators are considered as positive, while a high value of the remaining 7 indicators negative to development.

2 The five reform categories are related to: product and capital market; investments in the knowledge-based economy; labour market, social policy; and environmental policy reforms. 
member countries in the Lisbon process. There is lack of cross-national and quantitative social science research on the results of the Lisbon process and the Lisbon indicators provided by Eurostat. The usual simple analyses are not acceptable from a methodological viewpoint because they simply aggregate the Lisbon indicators on a 1:1 basis for a ranking of the EU-member countries.

The purpose of this study is to improve on the existing methods to measure the impact of reforms by two composite Lisbon strategy indices that quantify the level and patterns of development for ranking countries. We use cross-national development indicators and apply methodological advances mainly achieved in the framework of the United Nations development programmes to the problems raised by the Lisbon process. Two index approaches are used. Our first non-parametric approach is based on the methodology of the human development index (HDI) also used for measurement of globalization index 3 . The second parametric index is obtained from principal component analysis, widely known in the literature on social indicators of development. We compare the result from European countries with United State, Japan and also the newly industrialized Korea.

The composite index reduces the complexity of the 14 main Lisbon indicators and the ranking procedures. The LSI index is composed of six components: general economics, employment, innovation research, economic reform, social cohesion and environment, each generated from a number of the original main Lisbon indicators. Each of the index components develop differently over time and across countries. Such composite indices inform us about the individual countries' level of development and patterns of changes over time in their efforts to achieve the Lisbon goals. Thus, a breakdown of the composite index into major components provides possibilities to identify the sources of development at the country level and associate it with economic policy measures.

The empirical results show that by accounting for non-technology development factors US and Japan are not superior to several European nations. From the result we can observe that most countries improve their efficiency in achieving the Lisbon goals. These are reflected in the government attempt to improve their economic efficiency by revising national economic system and incentive scheme for the future.

Rest of the study is organized as follows. In the next section we introduce the Lisbon development strategy followed by a review of findings from previous studies in Section 3. In Section 4 we outline the composite strategy indices. The data and variables are presented in Section 5 and distribution and development of the indicators are discussed in Section 6. Variations in the composite indices across countries and over time are discussed in Section 7 and 8. The superiority of the development strategy in Scandinavia and Korea are discussed in Sections 9 to 11. Guideline for construction of a better index is presented in Section 12. The final Section 13 summarizes this study.

3 It should be noted that this HDI type index differs from the simple aggregation of the Lisbon indicators on a 1:1 basis. In the HDI type index the individual indicators are normalized prior to the aggregation, and in some cases certain factors are given different weights. Thus, in addition to the ranks the distance to the best in the HDI is quantitatively measured as well. 


\section{LISBON DEVELOPMENT STRATEGY}

At the European Council of March 2000 in Lisbon, the EU launched a comprehensive set of targets, to be achieved by implementing a series of integrated structural reforms over the next decade. The structural reforms are geared towards the general objective of becoming "the most competitive and dynamic knowledge-based economy in the world capable of sustainable economic growth with more and better jobs and greater social cohesion". This became known as the "Lisbon strategy" or the "Lisbon agenda".

In the year after, the Gothenburg European Council of June 2001 added an environmental pillar. As far as policy tools are concerned, the Lisbon conclusions make reference to the need to apply an appropriate macroeconomic policy mix, to modernise the European social model, to invest in people and combat social exclusion; to improve research and development (R\&D) and information and communication technology (ICT) policies, to stimulate competitiveness and innovation, and to compete at the internal market.

The wide scope of the Lisbon strategy has made it necessary to identify a set of operational targets or policy measures necessary to achieve the objectives. However, this is far from straightforward given the difficulty of distinguishing clear policy objectives from the policy reforms necessary to achieve these objectives. 4 Therefore the breadth of its scope makes the Lisbon strategy very different from earlier Community initiatives such as the internal market and economic and monetary union, which had more precisely defined programs.

\section{THE EXISTING DEVELOPMENT AND COMPETITIVENESS INDICES}

In recent years in a number of studies, several indices are introduced focusing on different forms of national competitiveness. The index of economic freedom (IEF), environmental sustainability index (ESI), the Arco technology index (ATI), technology assessment index (TAI), human development index (HDI) and globalization index (GI) are among such indices. 5

The Global Competitiveness Report of the World Economic Forum (WEF) and International institute for Management Development (IMD) in The World Competitiveness Report are example of the national competitive indices. But these reports do not analyze specific development areas in details. The definitions are too broad. Lall (2001) developed the competitiveness indices for developing countries and the analyses are from a development economics perspective.

Archibugi and Coco (2004) present a new index (ArCo) of technological capabilities that aims at accounting for developed and developing countries. The index takes into account a number of variables associated with technological change. Three main components are considered including: creation of technology, technological infrastructures, and

4 Council of the European Union, Brussels, 17 March 2005.

5 For examples of these indices see: UNDP (2001), Noorbakhsh (1998), Esty et al. (2005), Archibugi and Coco (2004), Heshmati (2003), and Dreher (2005). 
development of human skills. These are based on 8 indicators. For the policy makers national competitiveness is a serious concern, but many qualitative measures are vague. These weak theoretical and empirical foundation reduce the value of the indices for analytical or policy purpose.

Council of the European Union (2005) on the review of the Lisbon Strategy "Working together for growth and jobs: A new start for the Lisbon Strategy" therefore favours an increased focus around two principal tasks - delivering stronger, lasting growth and creating more and better jobs. The purpose of this report is to analyze the impact of Lisbon-type structural reforms. While these reforms do not correspond exactly to the present Lisbon package, they are designed to achieve the same goals as those set out in the strategy. However, it is extremely difficult to quantify the impact of the reforms as the heterogeneity of individual reform measures, the time lags in their implementation, the complementarities and trade-offs between reforms in different domains. The influence of short-term to medium-term developments make it also difficult to separate the effects of reforms undertaken from other determinants of performance.

The Lisbon reforms are classified into five categories: product and capital market reforms; investments in the knowledge-based economy; labour market reforms; social policy reforms; and environmental reforms. Also there are some who argue that one of the reasons why the Lisbon strategy has been relatively ineffective thus far is a lack of focus and clarity about its contents. This view is reflected in the report prepared by the High Level Group chaired by Kook (2004). Kook concludes that Europe needs to focus on growth and employment first without neglecting environmental and social concerns in the process. In line with the above findings in this paper we aim to improve on the limitation of the previous evaluation studies and find policy implications of our new index measures useful in ranking of countries and in their policy decisions to achieve the Lisbon goals.

\section{A COMPOSITE DEVELOPMENT STRATEGY INDEX}

Several attempts have been made to construct databases based on which human development type composite indices are computed. Kearney $(2002,2003)$ is one of such used to annually compute a composite globalization index. The index is composed of four major components: economic integration, personal contact, technology, and political engagement, each generated from a number of determinant variables, 13 in total (see also Heshmati 2003). This index can serve as a model for computation of a Lisbon strategy index (LSI). The LSI is then computed based on the normalization of 14 individual indicators and the subsequent aggregation using an ad hoc weighting system as follows:

$$
L S I_{i t}=\sum_{j=1}^{J} \sum_{m=1}^{M} \omega_{j m}\left\{\left(X_{j m i t}-X_{j m t}^{\min }\right) /\left(X_{j m t}^{\max }-X_{j m t}^{\min }\right)\right\}
$$

where $i$ and $t$ indicate country and time periods, $m$ and $j$ are within and between component subscripts, $\omega_{j m}$ are the weights attached to each indicator $(X)$, min and $\max$ are minimum and maximum values of respective indicator across countries in a given year to allow for year specific reference points. 
The index in (1) is suitable for indicators with an expected positive effect on development. In cases where the indicators are expected to have a negative impact on development the corresponding index is:

$$
L S I_{i t}=\sum_{j=1}^{J} \sum_{m=1}^{M} \omega_{j m}\left\{\left(X_{j m t}^{\max }-X_{j m i t}\right) /\left(X_{j m t}^{\max }-X_{j m t}^{\min }\right)\right\}
$$

where the two indices differ only by the nominator of the ratio. Alternatively, prior to the normalization in (1) the negative indicators are transformed to inverses, $(1 / X)$ reversing the impact.

The component's weights are chosen on an ad hoc basis and are constant across countries and over time. This LSI index can be used as benchmark index. Lockwood (2001), in computation of the globalization index, finds the ranking of countries to be sensitive to the way the indicators are measured, normalized and weighted. The weighting approach here is similar to the commonly used human development index (HDI), which is based on educational attainment, life expectancy and real GDP per capita (see Noorbaksh 1998).

There are at least two other alternative approaches to the LSI for computing a Lisbon strategy index; using the principal component or factor analysis (see e.g. Heshmati 2003; Andersen and Herbertsson 2003). 6 In this study we adopt both approaches hereafter, labelled as principal component index (PC) and factor analysis index (FA), respectively. However, since the two methods in normalized form give principal component scores with unit variance, we use only the PC results in the analysis.

Principal component analysis is a multivariate technique for examining relationships within a set of quantitative variables. Given a dataset with $p$ numeric variables, at most $p$ principal components can be computed; each is a linear combination of the original variables with coefficients equal to the eigenvectors of the correlation of the covariance matrix. The principal components are sorted according to the descending order of the eigenvalues, which are equal to the variance of the components. So for the readers, not familiar with technical notations, it might suffice to say that: PC analysis can be viewed as a way to uncover approximate linear dependencies among variables. This method gives a least square solution to the following model:

$$
Y=X B+E
$$

where $Y$ is an $n \times p$ matrix of the centred observed variables, $X$ is the $n \times j$ matrix of scores of the first $j$ principal components, $B$ is a $j \times p$ matrix of eigenvectors, $E$ is an $n \times p$ matrix of residuals, $n$ is the number of observations, $p$ the number of partial variables, and $j$ the number of variables or indicators of strategy. Here we minimize the sum of the squared residuals measured as distances from the point to the principal axis. In a traditional least squares estimation case, the vertical distance to the fitted line is minimized.

6 For recent surveys on the literature on the use of composite indices in different development research context see also Archibugi and Coco (2004) and Grupp and Mogree (2004). 


\section{DATA AND VARIABLE DEFINITIONS}

The database created by Eurostat 7 is used for the computation of the Lisbon strategy index. The part of the database used here constitutes a small balanced panel covering 34 countries 8 observed for the period 1995-2003. There were several missing units and missing observations. These are imputed, when available, using lag values for the same country, and when not available the missing EU units were imputed using average EU-25. The imputation was undertaken to avoid the use of unbalanced data and subsequent distortions in the reference points for the normalizations. Imputation with mean values has a minimum of effects on the index results. The data contain 14 structural indicators that are expected to proxy the countries development towards the Lisbon agenda goals. The 14 indicators are grouped into 6 groups including: general economics, employment, innovation research, economic reform, social cohesion and environment, each generated from a number of indicators.

The general economics component consists of two indicators: GDP per capita and average labour productivity. The two indicators are defined as GDP per capita and GDP per person employed measured in purchasing power standards (PPS) and normalized at EU25=100.

The second group, employment, is obtained from two indicators: total employment rate and employment rate of older people. The two indicators are obtained by dividing the number of persons aged 15 to 64 and 55 to 64 in employment by the total population of the same age group, respectively.

The third group, innovation and research, is based on the R\&D expenditure and youth education attainment levels. $R \& D$ expenditure is gross domestic expenditure on $R \& D$ as share of GDP. The education variable is defined as the percentage of young people aged 20-24 years having attained at least upper secondary education attainment level as share of the total population of the same age group.

The Economic reform component builds on two indicators. The comparative price level which is based on the price levels of final consumption by private households including indirect taxes normalized at EU25=100, and business investment. Business investment is measured as gross fixed capital formation by the private sector as a percentage of GDP.

Social cohesion is obtained from three indicators: the risk of poverty after social transfers, the unemployment rate and the regional dispersion in employment. The poverty indicator is defined as the share of persons with an equivalised disposable income below the riskof-poverty threshold, which is set at $60 \%$ of the national median equivalised disposable income after social transfers. The long-term unemployment defined as unemployment lasting 12 months and more is measured as percentage of the total active population.

7 The Lisbon database can be viewed at Eurostat website: http://epp.eurostat.cec.eu.int/

8 The Lisbon database contains information on 25 EU members, 5 East European and Turkey as nonmembers, USA and Japan, in total 33 countries. After adding South Korea, the sample is increased to 34 countries. 
Finally regional dispersion in employment is defined as the coefficient of variation of employment rates of the age group 15-64 across regions within countries.

The last component, the environment, is based on three variables: the green house gas, energy intensity of the economy and volume of freight transport. The emission variable is defined as percentage change since base year and targets according to Kyoto Protocol/EU Council Decision for 2008-2012 (in CO2 equivalents), indexed on actual base year=100. The energy variable is measured as gross inland consumption of energy in kilogram of oil equivalent per 1000 Euro relative to GDP (at constant prices, 1995=100). Finally, the freight indicator is an index of inland freight transport volume relative to GDP. It is measured in tone-km/GDP in constant 1995, 1995=100.

\section{DISTRIBUTION OF THE DEVELOPMENT INDICATORS}

Summary statistics of the 14 indicators are reported in Table 1 . In Table 1 we can observe large variations in the indicators underlying the calculation of the LSI index and its six components. The GDP per capita, R\&D expenditure, unemployment rate, regional dispersion in employment and energy intensity indicators show the largest dispersion measured by the coefficient of variation (standard deviation/mean). Labour productivity and energy intensity indicators show a large discrepancy between the mean and the median values suggesting a skewed distribution. The mean and median values of employment, business investment and regional dispersion in employment are overlapping.

Correlation coefficients among the various indicators are presented in Table 2. There is no statistically significant trend in the indicators. We find no systematic patterns in the sign and significance of correlation coefficients between and within the groups of indicators with the expected positive and negative effects on development. Business investment and educational attainment are unexpectedly negatively correlated with GDP per capita and labour productivity. The factors of risk at poverty, unemployment and energy intensity are found to be negatively correlated with the increases in GDP and labour productivity. However, the relationship with energy intensity and poverty risk and unemployment is positive.

The results from the computation of principal component analysis are reported in Table 3. Here two indices are computed (PC1 and PC2). The two indices differ by in the first one no account is taken for the expected sign of the indicators, while in the second such account is allowed for. ${ }^{9}$ In each approach four principal components are found with eigenvalues exceeding one. In order to utilize all power in explaining variations in the data, the final indices are computed as averages of the four components. In the aggregation the share of variance explained by each component is used as weights. The share of total variance explained by the first four principal components is $71.78 \%$ and $69.61 \%$, respectively.

9 The difference between PC1 and PC2 results is that, in computation of PC2 we account of the fact that the comparative price level in the economic reform and factors of social exclusion environment are to be seen in a negative light from the social policy and the general Lisbon policy perspective. The difference between the two indices is that in PC1 the original positive and negative factors (X) are used, while in PC2 the inverses $(1 / \mathrm{X})$ of the negative factors are used. 
The use of parametric PC analysis has a number of disadvantages compared to the nonparametric Lisbon strategy index. One disadvantage is that PC methods do not allow decomposition of the overall index into the underlying six components as in the case of LSI. Such decomposition would require, first, the application of PC analysis on each component separately, and then the aggregation of the components into a single index by assigning some weights to each component. A second disadvantage is that PC approach does not distinguish between bad indicators (like negative expected effects of high levels of emission or high levels of energy intensity) and good indicators (like positive expected effects of high GDP per capita and high labour productivity) for the strategy index. Such separation is possible only if the variables with expected negative effects are transformed prior to the computation by using the inverse as is done here or by reversing the ranks of the variables as in equation (2).

The summary of the six components of the composite LSI index and the two composite PC indices are reported in Table 4. The two composite indices differ in distribution, by their reverse difference between mean and medians. The level differences among the three composite indices are due to different weighting systems used in their computations and are not a matter of concern.

The correlation coefficients among the 14 indicators corresponding to those reported in Table 2, but based on normalized indicators, are reported in Table 5. In normalized form there is a statistically significant trend in development of most of the indicators over time. Business investment, prices, emission and freight are negatively correlated with several other indicators.

Economic reform is negatively correlated with the remaining five components (see Table 6). However, the correlation coefficient with environment is statistically not significant. Economic growth and social cohesion are positively correlated. Employment and innovation research are also positively correlated with GDP per capita. Economic reform is negatively correlated to both of the composite indices. The two composite indices are positively correlated but only at the low level of 0.54 . Social cohesion and the general economic component are positively correlated (0.38). Social cohesion is in turn positively correlated with the levels of GDP and labour productivity, measured in both normalized and original forms, but negatively correlated with changes in these two variables (see Table 7). The finding of a positive association between social cohesion and general economic condition (level of GDP and labour productivity) is in favour of European model of welfare policy suggesting that investment in welfare enhances productivity of labour.

\section{VARIATION IN THE LISBON STRATEGY INDEX ACROSS COUNTRIES}

The normalized indicators ranging in the interval 0 and 1 , used in the computation of the non-parametric LSI index in the form of country mean values are reported in Table 8. The countries are ranked in ascending order of the composite LSI index. Sweden, Norway, the USA and Austria are ranked as the highest. Despite the high ranks, Sweden has quite low scores in the price level and business investment components, Norway in prices and frights, and USA in the regional distribution of employment and emissions. Japan is ranked very low as number 12, partially a consequence of its high price levels. 
South Korea is ranked as number 8. Its high rank is a reflection of the relative low price levels, low energy intensity, high work moral and very high old age workforce participation. Bulgaria, Turkey and Malta, despite their low prices and their low levels of energy intensity and frights, are amongst the lowest ranked countries.

A breakdown of the LSI index into the underlying six components provides the possibility to identify the sources of development and to quantify their impacts on the development of individual countries. The results are reported in Table 9 where the countries again are ranked in ascending order of the LSI index, with Sweden, Norway, USA, Austria and Netherlands ranked highest (see also Figure 1). The economic reform component is quite low for Norway and Sweden, as the price levels are very high in these countries and low business investment is a result of a combination of the high tax rate and low saving rate. Ireland is surprisingly ranked as a medium performer. The low scores in employment, social cohesion and innovation research negatively affects its rank. Italy is ranked as $31^{\text {st }}$ and with the exception of general economics and environment components it achieves low scores in the remaining four components, in particular in employment and social cohesion.

There is a positive trend in emission and employment indicators suggesting a reduction in emission and unemployment rates over time. In comparison between the individual and groups of countries, the EU15 is ranked higher than the EU12 and EU25, although the USA, Korea and Japan are ranked highest in total. The countries and groups of countries differ by the individual indicators (see Table 8). The high rank of Korea in the nonparametric index as number $8^{\text {th }}$ is changing to much lower ranks, $23^{\text {rd }}$ and $16^{\text {th }}$ respectively in the parametric indices (see Table 9).10 The difference might be attributed to incomparability in data.

Over time there are positive trends in employment, social cohesion, environment and the overall composite LSI index, while declining tendency in the general economics component. The dispersion in development among the EU countries is very large as shown in Table 9. When countries are grouped and the average EU is considered, USA, Korea Japan rank higher than the average EU countries. The East European countries, including Turkey, rank lowest.

If we, instead of the non-parametric LSI index rank countries by the parametric principal component PC1 and PC2 indices where the index is based on weighted averages of the first 4 principal components, the rank of some countries changed significantly (see Figure 2). The highest transition in position of countries is observed when comparing LSI and PC1. The difference is a consequence of the failure in PC1 to distinguish between good and bad indicators. The losers in ranks are Sweden, Czech Republic, Korea, Finland and Germany, while the winners are Portugal, Iceland and Spain. Inequality in the levels of different components of the strategy index across countries is shown in Figure 3.

In comparison of LSI and PC2 which both are based on a case where one accounts for the bad and good aspects of the indicators, but the two indices differ by parametric and non-

10 It was rather difficult to add Korea to the Lisbon database. Inconsistency in the data might be the cause of major shifts in the rank of Korea and sensitivity of the computation methods. 
parametric natures of the indices, the ranks of countries changes less. Norway is the highest ranked followed by Sweden, Denmark and Austria all of which outperform USA and Japan (see Table 9). The winner is Korea and the losers are Japan and Germany. The correlation between the two LSI and PC2 in Table 6 is very high (0.925) and it allows us to say that the results could claim validity in favour of them.

\section{THE DYNAMICS OF THE STRATEGY INDICES}

In the previous section we discussed that in normalized form there is a statistically significant trend in development of several indicators over time. We have shown that business investment, prices, emission and freight are negatively correlated with several other indicators. We also found that there is a positive trend in emission and employment indictors suggesting a reduction in emission and unemployment rates over time for many countries. Further, we found that all three indices are increasing over time.

Our investigations also allow us to show the dynamics of changes taking place, as the countries of the Union struggle to achieve the Lisbon goals. The 1995-2003 period average percentage changes in the three composite indices labelled as $\Delta I$ are computed as:

$$
\Delta I=\sum_{t=1}^{9}\left[\left(\left(I_{i t}-I_{i t-1}\right) / I_{i t-1}\right) \times 100\right] / T-1
$$

for each country, presented in the Table 9. $\mathrm{T}$ is the number of time periods. The results show that Spain, Bulgaria and Ireland had the most rapid positive changes to be reported, while the new member Poland and candidate countries Romania experience negative average period changes in LSI and PC2 indices. By the PC2 index, Bulgaria experienced the highest negative change, while Estonia and Latvia the highest positive changes. The average positive changes in the three indices in the case of Korea and Japan are relatively low compared to the EU country group averages (see Figure 4 and 5). This might be due to the strong impacts of the Asian economic crisis on these countries development compared to the growth of best performing countries.

Table 10 shows that the year to year variations is highest in relation to economic reform and environment components. However, these changes are not associated with EU countries, rather than to other countries foremost Japan, Korea and USA. Innovation research and social cohesion show stability over time with small year to year changes. Although, EU has been active in its social reforms, while the situation in Korea deteriorated as a result of the financial crisis of 1997.11

11 For details about the economic development strategy in Korea, the effects of financial crisis and the country’s state of technology and competitiveness see Branscomb and Kim (1996), Lee (1997), Cooper (1999) and Chung and Richard (2002). 


\section{THE FACTOR ANALYTICAL RESULTS 12}

From the viewpoint of international social welfare policy, the multivariate calculations presented in above, based on principal components analysis of all the 14 structural Eurostat indicators show the following points.

The results show that a development strategy, based on research and development, will be most successful in reducing poverty. The non-normalized correlation matrix (Table 2) documents that the highest negative correlation of the Eurostat poverty rate is with $R \& D$ followed by employment. Investment in $R \& D$ is probably the most important measure to enhance the European competitiveness and technology leadership, as well as in creation of new jobs outside the old line industries.

If we want to reduce the complexity of the 14 indicators, the usual ranking procedures, based on average rank with equal weights, employed by EU employees are insufficient. The principal components analysis is a better and less restrictive composite index and results shows that there are 4 underlying factors that explain 70 to $72 \%$ of the total variance of all 14 Lisbon indicators combined, and that these 4 Lisbon dimensions have the following loadings with the original variables.

The most important factor explains $38 \%$ of the variance, and achieves the highest loadings with the comparative price level, the GDP per capita, labour productivity, high employment, research and development rate and the reduction of the energy intensity of the economy. This most important factor can simply be called development of productive forces. Sweden, Norway and the US lead the field here; while the worst performance is found in Bulgaria, the Slovak Republic and Poland. With it, some $14 \%$ of the reduction of the Eurostat poverty rate is explained as well, and it also explains $31 \%$ of the reduction of the unemployment rate. In other words, by concentrating on the growth factor alone, Europe would be able to influence around $1 / 6$ of its poverty rates and $1 / 3$ of its unemployment rates. Again, research and development plays an important role here. In the EU, Finland is the research and development record holder, with Germany, Denmark and France behind the United States. It is to be noted that R\&D is the only Lisbon factor, where the US have a real advantage over most European states.

There is a second factor which we call it social exclusion, not very much related with the other dimensions of policy, and rather reflecting historical and long-term trends of social exclusion in societies. The best performance in avoiding social exclusion is to be found in Sweden, the Czech Republic and Norway, while Malta, Italy and Turkey have the worst performance. It explains $14 \%$ of the total variance of the Lisbon indicators over the last decade, and achieves its highest loadings with the lack of educational attainment. Typically, we encounter such high rates of social exclusion in the European South with its long-standing patterns of internal polarization between a relatively richer regional centre and poor South. The Central European and the Scandinavian countries are homogeneous and do not suffer from these often long-standing and historical exclusion patterns that evolved in the process of nation-building in modern times. The factor explains $27 \%$ of the variance of poverty rates.

12 Sections 9 and 10 have benefited from the discussion in Tausch and Heshmati (2005). 
The 14 main structural Lisbon indicators, as they are constituted at present, also measure the power of the freight lobby in Europe, a third important factor. Estonia, Ireland, Spain, Latvia, Greece, Lithuania, Austria and Portugal all experienced freight transport increase over the last years. The freight lobby factor explains $12 \%$ of total variance on its own, and is responsible for $26 \%$ of the poverty rate in the nations analyzed by Eurostat. The overall best performance in avoiding the freight lobby index is to be found in Bulgaria, Poland and Belgium, while the worst performances are found in Estonia, Portugal and Ireland.

Only the $4^{\text {th }}$ factor, business investment and neo-liberal investment climate, is more strongly related to the growth-scenarios of neo-classical economics. The overall weights of this factor are strongest in Austria, Greece, and the Slovak Republic. The weakest performance is to be found in Sweden, Japan, and Cyprus. The product market reforms, capital market reforms, and labour market reforms are elements of a neo-liberal strategy. Our approach however stresses the importance of the factors knowledge-based economy, avoiding social exclusion, and overcoming the power of the freight lobby as an important step in the direction of a better environment as the three most important central pillars of a successful Lisbon strategy. The new liberal factor contribution to explain variance in the total model is only $7.8 \%$, while the knowledge-based economy factor 1 explains 39\% of the variance of the 14 structural indicators, social exclusion 14\%, and the freight lobby $12 \%$.

A real Lisbon strategy would be to go for factor 1, i.e. to learn from the really advanced countries like Sweden, Norway or the United States, ideally combining high labour productivity, high research and development, high employment rate and a tendency towards lower energy intensity. A concentration on these factors would unquestionably solve the problems of European employment, but at the price of high green house gas emissions. The model would considerably reduce poverty and would also reduce energy intensity. Six indicators, green house gas emissions; employment of older workers; at risk of poverty; dispersion of regional employment; educational attainment, and freight transport are not very well explained by Factor 1 and have more than half the variance unaccounted for by Factor 1, which combines strategies aiming at the development of productive forces.

\section{TWO EUROPEAN DEVELOPMENT MODELS}

We would not like to conclude this paper without referring to two important phenomena, which emerge from our data analysis. First, as to be expected in a factor analytical model, which we used, there is a relatively small correlation between the 4 different factors identified in above. However, the strong linear relationship between development level and social exclusion emerges from our analysis in space and time for each country. The strength of the relationship is extraordinary, qualifying thus any application of the "growth is good for the poor" strategy on the European level. Growth will most probably polarize in the poorer countries, before it really starts to re-distribute.

It is also shown that the powerful European freight lobby, which dominates a great deal of the European political economy, will also increase in power along development, and 
only can be successfully disciplined at very high stages of development. The same nonlinear effect might hold for business investments as well.

These results indicate that the present logic suggests a strengthening of the forces of inequality, of the freight lobby and also of the neo-liberal business investment strategy at the middle stages of development. This shows that there are rather two approaches to the Lisbon process in place - one, a research and development oriented Scandinavian model and a second approach, based on the neo-liberal Central European transformation model.

We are rather sceptical about the short-term and medium term prospects of the "old centre" of Europe, the larger EU countries including France, Germany and Italy, which perform poorly on most of our indicators used. The picture confirms the laggard nature of societal processes especially in Germany. With the Germany a former "growth locomotive” affected by such a deep crisis, Europe would be well advised to follow one of the two policy options, i.e. either the Scandinavian model, based on high R\&D and a high exchange rate in relation to the purchasing power, i.e. a position in the world system as a centre, and not as a periphery, or the Central European growth model. In terms of the social implications of the model, our personal preference is given to the Scandinavian alternative, paradoxically much nearer to the United States than the neo-liberal Central European alternative. The freight lobby strategy is no alternative and does not stimulate long-term economic growth, they also show that the LSI index and the PC2 index as well as percentage change in LSI index are only weakly associated with long-term economic growth. The strongest correlation is achieved by the R\&D factor 1 which was called as the development of productive forces.

\section{THE KOREAN DEVELOPMENT STRATEGY}

Korea is ranked as number 8 by the LSI Index (see Table 9). This position is better than Japan's, and Korea has a higher score in innovation and research than EU but lower than USA and Japan. Also Korea's economic reform is quite high as a result of lower price level than EU and a higher business investment rate (see Table 8). The reason to emphasize Korea's development model is that Korea's rapid growth has been a source of admiration. It also stabilized the economy very short after the 1997 economic crisis and the rate of rapid recovery after the crisis makes the country very interesting from the perspectives of growth and development strategy. Thus many aspects of its policy can serve not only as a model for economic development, but also an experiment field for development of new industries, and to achieve high innovativeness and competitiveness to both developing and developed countries as well.

There are several key factors deriving the Korea's dramatic economic development. World Bank reports that, the high investment ratio in Korea is to be found in the structure of demand. Investment ratio is defined as the ratio of gross domestic investment to gross domestic product. From 1965 to 1990 Korea's investment ratio rose from well below to well above the group average with 23-24 percent. This was supported by high saving rate and low borrowing cost. Korean government's planning and industrial policy both reduced future uncertainty, while the rapid growth has offset investors' error. 
Korea's investment in human resources and technology as infrastructure for its economic development started from the mid 1960. From 1962-72 the Korean economic development was based on an export-led growth strategy, in 1973-1981 it was focusing on the heavy and chemical industry, while 1982-1992 is the period of stabilization and liberalization to promote competition and efficiency of firms and industries.

Korea focused on technology development from the early 1980. Since the 1980, Korea has rapidly modernized its industrial structure by promoting capital investment and technology development a policy to adjust toward high value-added and technology intensive production technology. From this time the R\&D investment increased dramatically. A concept of National Innovation System was introduced by Freeman (1987), Lundvall (1988), and Nelson (1987). They emphasized the differences in innovation ability among Nations and underline the role of government. Korea is committed to technology based innovation as the primary source of economic transformation to realize the goal of reaching the level of the G7 group members' development in early 21 century. Korean government fiscal commitment to annually increase R\&D investment by $25-30 \%$ is one measure to achieve this vision. As the result of such policy GDP per capita grow from \$300 in 1955 to more than \$10000 in 1995.

Kuznets (1994) on Korea's economic development state that, the key characteristics of South Korea's economic development since the mid 1960s are: high investment rates, labour market competition, export orientation and a strong interventionist government. Indices of human resource development based on post-primary school enrolment ratios for 112 countries in 1960 and 1965 show that Korea's educational attainment was the same as that of semi-advanced countries like Italy and Spain and much higher than that of other countries with equally low per capita GNP (Herbison, 1970). McGinn (1980) found that what is unique about Korean development from 1945 is that a high level of human resources was developed early and despite low per capita income. The high level of investment in education was an important driving force of the Korean economic development. Education influences development by increasing skills and expanding learning capacity, which in turn result in a higher productivity, investment and welfare.

From the data for the empirical analysis, we can see that Korea obtained a high score in education, $\mathrm{R} \& \mathrm{D}$ expenditure and business investment. The ranking by education is better than that of EU despite a lower level of GDP per capita (see Table 8). This indicates that although the role of state and the industrial policy have been changed markedly after the crisis, the key deriving factors of Korea economic development remain the same.

It is to be noted that the rank of Korea by the principal component analysis is 23 and 16 . The later is preferred as in the similarity with the LSI index it accounts for the expected signs of the development indicators prior to their use in the multivariate analysis. The result of PC1 and PC2 indices shows that Korea is lower ranked that average EU, Japan and USA (see Table 9). The results show despite its great progress in recent decades, Korea has a high risk of poverty and a higher regional dispersion in employment than EU, Japan and USA, as well as a lower labour productivity measured as GDP per employed person (see Table 8). The high risk at poverty and dispersion in employment are a direct consequence of the deep economic crisis. The post crisis gradual increases in the level of GDP per capita and improvement in the employment rates suggest significant catch ups. 
In summary the results suggests that Korea has advanced to become a technologically advanced country with great improvement in development capability, competitiveness, and it competes with the highly developed nations like EU, Japan and USA. However, Korea lags behind in social reforms compared to the developed countries and in particular the European. The result shows that (see Table 10) Korea's percentage changes in social cohesion in the aftermath of the economic crisis is negative. However, the percent changes in environment are very high compared to other countries suggesting effectiveness of investment in environmentally friendly technologies both for domestic consumption and as well as for competitive export market.

Korean rapid economic growth, investment in infrastructure for economic and technology development can serve a model for the pace of development in many other countries. The rapid economic growth was due to state planning mechanism which prioritised development of productive rather than social infrastructure. Since the economic crisis, to a large extent, stemmed from the state's planning mechanisms and policy intervention policy, the Korean government must analyse the causes and effects of the weak but critical factors mentioned here. These should be accounted in the future development policy. As the goals of education and technological capability are well achieved, more attention should be paid to construction of a globally competitive social environment.

\section{GUIDELINES TO CONSTRUCT A BETTER INDEX}

The development strategy index in this study is easily distinguished from previous ones. Unlike previous studies, which are often based on analysis of individual indicators to proxy development, the Lisbon strategy index covers simultaneously all aspects of the development, i.e. the 14 main structural Lisbon indicators. These aspects of development vary greatly across countries and over time. However, the time period here is very short and covers only post 1995 period. The reason for choosing the post 1995 period is that construction of a composite index for consistency in comparison and reference points requires a balanced panel data limiting the length of the time period.

Despite the data limitations and the short time coverage, our results provide a better picture of the technology gap between EU, USA, Japan and Korea. With the help of the new index we can better quantify the heterogeneity in the process of development, identify possible factors causing the gap, and to identify factors with strong impacts on the catching up of countries lagging behind in their development.

The new composite index was shown to be much better than the traditional single factors in ranking of countries. However, it can be improved significantly in a number of dimensions. A new index should take an axiomatic approach that sets out its desirable properties and provides a family with indexes that fulfil such properties. Such an index should fully quantify development by including several other relevant components. It should include some other (and non-monetary) measures of welfare, health, income inequality, happiness, gender equality, redistributions, other environmental aspects, wage inequality, democracy and conflict, inflow of foreign direct investment 13 , etc.

13 For a recent review of the new global determinants of flow of FDI see Addison and Heshmati (2004). 
Industrialized countries and EU in particular dominate the current sample. The overweighing of the advanced industrial countries in the sample results in smaller and slow changes in mean development over time. Furthermore, it also biases the composition of the effects from a reform/accession country perspective. At the end of the day, the sample of countries, covered by Eurostat, should politically correspond to the Wider Europe perspective of the Commission and should include both TACIS project and MEDA project countries in East Europe and the Mediterranean area. The sample in addition to USA, Korea and Japan should further include developing and potential competitor countries such as China, India and some other newly industrialized countries in South East Asia and Latin America.

Identification of the major determinants of development and quantification of their effects on the ranking of countries are key issues forming the basis on which policy options can be provided. Analysis will help to identify different ways to promote development and to reduce the negative effects of development on the poor, such that policy measures with such negative effects are accompanied by redistribution policies and an improvement in social protection of the vulnerable groups.

\section{SUMMARY AND CONCLUSIONS}

This paper provides the result of development strategy employed by most industrialized and several developing and transition countries by measuring three composite Lisbon strategy indices that quantify the level and temporal patterns of development for ranking countries. The database used here constitutes a small balanced panel covering 34 European Union, some East European, Turkey, USA, Japan and Korea observed for the period 1995-2003.

Lisbon strategy index is composed of 14 indicators grouped into six components including general economics, employment, innovation research, economic reform, social cohesion and environment. The current index is certainly an improvement over the previous simple indicator indices. However, it has a number of limitations. We suggest improvements along several dimensions. A new index should have desirable properties of an index number and fully quantify development by including several other relevant components including other measures of welfare, health, inequality, happiness, gender equality, redistribution, other environmental aspects, wage inequality, democracy and conflict, etc.

The result shows that computation of a composite strategy index is very informative and decisive in ranking the sample countries. We identify the main contributing components to economic development and thereby compare the development of countries. The results are useful to decision makers of development policy. In general we can say that certain factors enhance development more than others. However, countries development relies on different drivers of their development. Identification of positive and negative factors to development of individual countries will help in the design of policies that best promote their growth strategies.

We identify the most important factor called development of productive forces. The highest loadings is achieved with the comparative price level, the GDP per capita, labour 
productivity, high employment, research and development rate and the reduction of the energy intensity of the economy. This factor alone would be able to influence strongly poverty and unemployment rates. The results suggest that a development strategy, based on research and development, will be successful in reducing poverty. A second factor of social exclusion is reflecting historical and trend of social exclusion in society achieves its highest loadings with the inequality in education. The power of the freight lobby in recent years as a third factor should not be ignored. The product market reforms, capital market reforms, and labour market reforms are elements of the fourth factor of neoliberal strategy. Our approach however stresses the importance of the factors knowledgebased economy, to avoid social exclusion, and to overcome the power of the freight lobby as an important step in the direction of a better environment as the three most important central pillars of a Lisbon strategy.

Korea has advanced to become a technologically an advanced economy with great potential for further improvement in development capability, and competitiveness. However, Korea lags behind in social reforms compared to the developed countries and in particular the European. As the Korean economy has recovered from the deep economic crisis, it should embark on introduction of social reforms to share a larger part of the positive returns from growth and to invest it in improvement of the quality of the life of its citizens. Tendencies for the direction of such policy are evident from the positive changes in environmental component of the development strategy index. Thus Korean rapid economic growth, investment in infrastructure for economic and technology development can serve as a model for economic development in many other developing and transition countries. The Korean government must analyse the causes and effects of the weak but critical factors to its future economic, social and technology policies. 


\section{REFERENCES}

Addison T. and A. Heshmati (2004), "The New Global Determinants of FDI Flows to Developing Countries: The Impacts of ICT and Democratization", Research in Banking and Finance 4, 151-186.

Andersen, T. M., and T. T. Herbertsson (2003). "Measuring Globalization”. IZA Discussion Paper 2003: 817.

Archibugi D. and A. CoCo (2004), "A New Indicator of Technological Capabilities for Developed and Developing Countries (ArCo)”, World Development 32(4), 629-654.

Branscomb L.M. and Y-H. Kim (1996), Eds. "Korea at the Turning Point: InnovationBased Strategies for Development”, Westport, Connecticut, London: Praeger.

Chung J.Y. and J.R. Richard (2002), "The Political Economy of Development and Environment in Korea”, Routledge Studies in the Growth Economies of Asia.

Cooper R. (1999), "The Asian Crisis: Causes and Consequences”, World BankBrookings Institution Conference on Emerging Markets and Development, Department of Economics, Harvard University.

Dreher A. (2005), "Does Globalization Affects Growth? Empirical Evidence from a New Index”, Unpublished Manuscript, University of Konstanz, Department of Economics, Germany.

Esty D.C., L. Marc, S. Tanja and A. Sherbinin (2005), "Environmental Sustainability Index: Benchmarking National Environmental Stewardship”, New Haven: Yale Center for Environmental Law and Policy.

European Commission (2005a), Euro-Lex: Communication to the Spring Council, "Working together for growth and jobs - A new start for the Lisbon Strategy", COM (2005) 24 (February 2005).

European Commission (2005b), "A new start for the Lisbon Strategy", available at: http://europa.eu.int/growthandjobs/index_en.htm

European Commission (2005c), "The economic costs of non-Lisbon. A survey of the literature on the economic impact of Lisbon-type reforms”, SEC (2005) 385 (15 March 2005).

Freeman. C. (1987), “Technology Policy and Economic Performance: Lessons from Japan”, London: Frances Printer.

Grupp H. and M.E. Mogee (2004), "Indicators for National Science and Technology Policy: How Robust are Composite Indicators?”, Research Policy 33, 1373-1384.

Harbison F.H. (1970), "Quantitative Analyses of Modernization and Development. Department of Economics”, Research Report series, no.115, Princeton, NJ: Princeton University.

Heshmati, A. (2003). "Measurement of a Multidimentional Index of Globalization and its Impact on Income Inequality”, WIDER Discussion Paper 2003/69. Helsinki: UNUWIDER.

Kearney A.T. Inc. and the Carnegie Endowment for International Peace (2002), “Globalization’s Last Hurrah?”. Foreign Policy, January/February: 38-51. 
Kearney A.T. Inc. and the Carnegie Endowment for International Peace (2003), “Measuring Globalization: Who's up, who's down?”, Foreign Policy, January/February: 60-72.

Kook W. (2004), "Facing the Challenge: The Lisbon Strategy for Growth and Employment”, High Level Group Report, November.

Kuznets P.W. (1994), “Korean Economic Development”, Westport, Connecticut, London: Praeger.

Lall S. (2001), "Competitiveness Indices and Developing Countries: An Economic Evaluation of the Global Competitiveness Report”, World Development 29(9), 15011525.

Lee K. (1997), “Korean Industries, Technology and Competitiveness”, KungMunSa.

Lockwood B. (2001), "How Robust if the Foreign Policy/Kearney Index of globalization?”, CSGR Working Paper 79/01.

Lundvall B. (1988), "Innovation as an Interactive Process: From User-Producer Interaction to the National Innovation Systems", in G. Dosi et al., eds. Technical Change and Economic Theory, Printer London.

McGinn N.F. (1980), “Education and Development in Korea”, Cambridge, MA: Harvard University Press, Korea Development Institute.

Nelson R. (1987), "Understanding Technical Change as an Evolutionary Process", North-Holland.

Noorbakhsh F. (1998), "The Human Development Index: Some Technical Issues and Alternative Indices” Journal of International Development 10, 589-605.

Tausch A. and A. Heshmati (2005), A Composite Lisbon Strategy Index, Unpublished Manuscript. 
Table 1. Summary statistics of structural development indicators, $\mathrm{n}=306$ obs.

\begin{tabular}{|c|c|c|c|c|c|c|}
\hline Variable & Definition & Mean & Median & Std Dev & Minimum & Maximum \\
\hline year & year of obs. & 1999.0000 & 1999.0000 & 2.5862 & 1995.0000 & 2003.0000 \\
\hline gdp & gdp per capita & 89.2997 & 87.7500 & 41.9221 & 25.4000 & 219.1000 \\
\hline lab & labour productivity & 86.4000 & 99.1000 & 33.3966 & 28.5000 & 156.7000 \\
\hline emp & employment rate & 62.3046 & 62.3000 & 7.3469 & 45.8000 & 77.5000 \\
\hline old & old age employ. rate & 39.7791 & 37.4500 & 13.1369 & 17.3000 & 68.6000 \\
\hline edu & education enrolment & 76.4235 & 77.8500 & 12.8048 & 39.0000 & 96.1000 \\
\hline $\exp$ & R\&D expenditure & 1.5007 & 1.3450 & 0.9104 & 0.2300 & 4.2700 \\
\hline inv & business investment & 18.3366 & 18.0000 & 3.2112 & 9.5000 & 32.1000 \\
\hline pri & prices & 87.9010 & 89.0500 & 33.5067 & 27.1000 & 198.7000 \\
\hline pov & risk at poverty & 15.2124 & 15.0000 & 3.9593 & 8.0000 & 25.0000 \\
\hline une & unemployment rate & 3.9013 & 3.5000 & 2.7559 & 0.2000 & 12.2000 \\
\hline dis & regional emply. disp & 9.2951 & 9.1000 & 4.3196 & 1.6000 & 17.5000 \\
\hline emi & emission rate & 93.5546 & 98.3000 & 24.3756 & 35.0000 & 149.7000 \\
\hline ene & energy use & 494.7541 & 259.2700 & 486.1417 & 119.0000 & 2543.7800 \\
\hline fre & freight & 100.8124 & 100.0000 & 19.5020 & 31.8000 & 190.0000 \\
\hline
\end{tabular}

Table 2. Pearson correlation of non-normalized indicators, $n=306$ obs.

\begin{tabular}{|c|c|c|c|c|c|c|c|c|c|c|c|c|c|c|c|}
\hline & year & gdp & $1 a b$ & emp & old & edu & $\exp$ & inv & pri & pov & une & dis & emi & ene & fre \\
\hline$\overline{\text { year }}$ & 1.00 & & & & & & & & & & & & & & \\
\hline gdp & 0.03 & 1.00 & & & & & & & & & & & & & \\
\hline$l a b$ & 0.03 & $0.91 a$ & 1.00 & & & & & & & & & & & & \\
\hline emp & 0.07 & $0.55 a$ & $0.35 a$ & 1.00 & & & & & & & & & & & \\
\hline old & 0.08 & $0.23 a$ & $0.09 c$ & $0.69 a$ & 1.00 & & & & & & & & & & \\
\hline edu & 0.07 & $-0.16 a$ & $-0.14 a$ & $0.17 a$ & 0.06 & 1.00 & & & & & & & & & \\
\hline $\exp$ & $0.09 \mathrm{c}$ & $0.63 a$ & $0.60 a$ & $0.51 a$ & $0.38 a$ & -0.05 & 1.00 & & & & & & & & \\
\hline inv & 0.05 & $-0.19 a$ & $-0.24 a$ & 0.01 & $-0.15 a$ & $0.13 a$ & $-0.25 a$ & 1.00 & & & & & & & \\
\hline pri & 0.04 & $0.79 a$ & $0.81 a$ & $0.53 a$ & $0.38 a$ & -0.07 & $0.71 \mathrm{a}$ & $-0.30 a$ & 1.00 & & & & & & \\
\hline pov & -0.04 & $-0.32 a$ & $-0.23 a$ & $-0.39 a$ & 0.00 & $-0.21 a$ & $-0.53 a$ & $0.10 \mathrm{c}$ & $-0.25 a$ & 1.00 & & & & & \\
\hline une & -0.07 & $-0.57 a$ & $-0.39 a$ & $-0.69 a$ & $-0.53 a$ & 0.06 & $-0.43 a$ & 0.06 & $-0.47 a$ & $0.23 a$ & 1.00 & & & & \\
\hline dis & -0.02 & -0.03 & 0.02 & $-0.33 a$ & $-0.17 a$ & $-0.20 a$ & $-0.16 a$ & -0.04 & -0.00 & $0.21 a$ & $0.17 a$ & 1.00 & & & \\
\hline emi & 0.04 & $0.45 a$ & $0.53 a$ & $0.22 a$ & $0.24 a$ & $-0.30 a$ & $0.29 a$ & $-0.10 c$ & $0.49 a$ & 0.07 & $-0.42 a$ & -0.05 & 1.00 & & \\
\hline ene & -0.08 & $-0.65 a$ & $-0.74 a$ & $-0.28 a$ & $-0.19 a$ & $0.18 a$ & $-0.51 a$ & 0.07 & $-0.70 a$ & $0.10 \mathrm{c}$ & $0.45 a$ & 0.05 & $-0.69 a$ & 1.00 & \\
\hline fre & 0.01 & 0.02 & 0.05 & 0.08 & $0.20 a$ & -0.08 & $-0.14 a$ & $0.16 a$ & $0.10 c$ & $0.24 a$ & $-0.20 a$ & 0.08 & $0.13 b$ & $-0.13 b$ & 1.00 \\
\hline
\end{tabular}

notes: less than $1 \%$ (a), 1-5\% (b) and 5-10\%(c) levels of significance.

Abbreviations: GDP per capita (gdp), labour productivity (lab), employment rate (emp) old age employment rate (old), Education enrolment (edu), R\&D expenditure (R\&D), business investment (inv), prices (pri), risk at poverty (pov),

Unemployment rate (une), regional employment distribution (dis), emission rate (emi), energy use (ene), freight (fre). 
Table 3. Summary of principal component and factor analysis, $n=306$ obs.

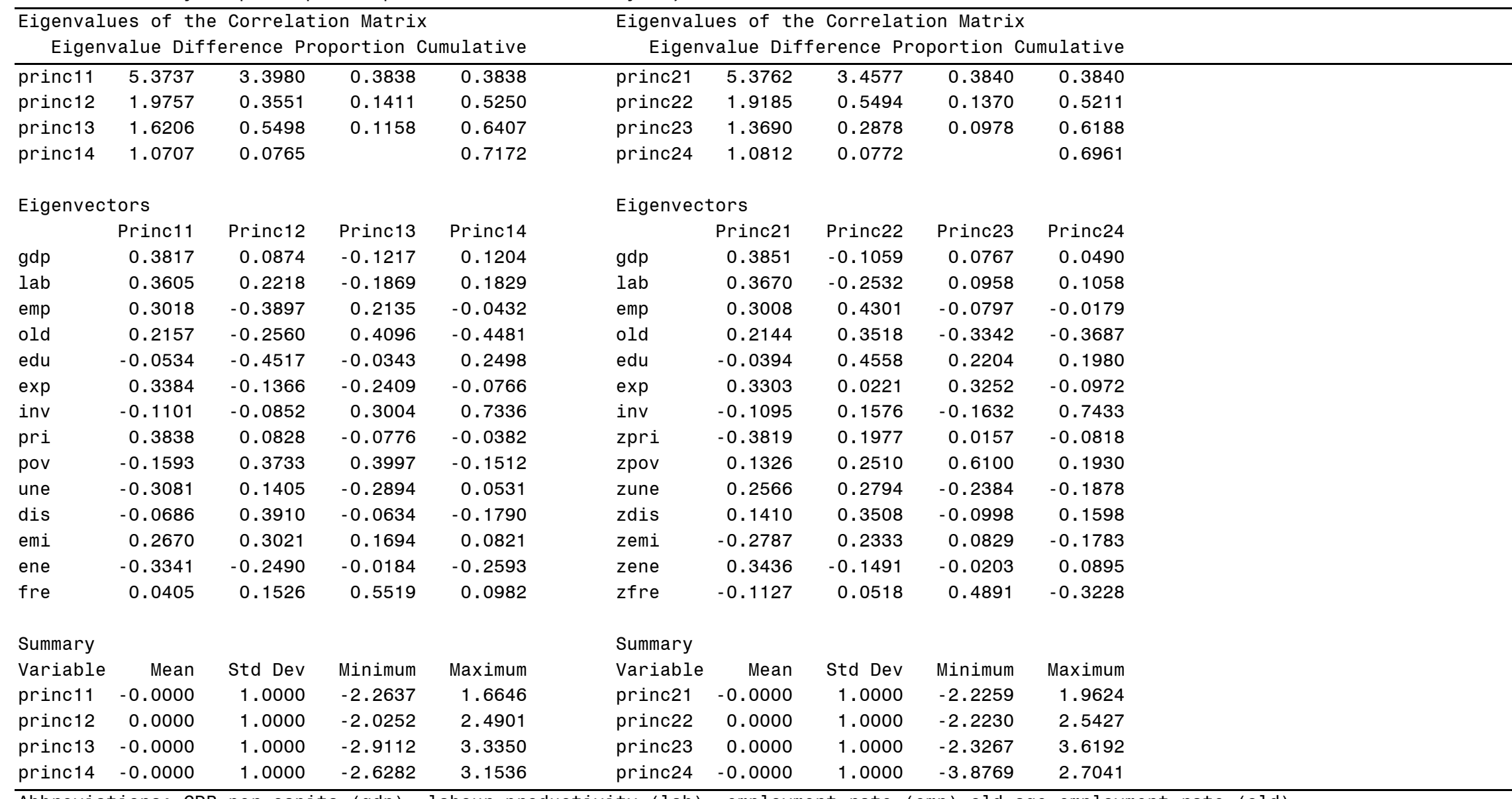

Abbreviations: GDP per capita (gdp), labour productivity (lab), employment rate (emp) old age employment rate (old),

Education enrolment (edu), R\&D expenditure (R\&D), business investment (inv), prices (pri), risk at poverty (pov),

Unemployment rate (une), regional employment distribution (dis), emission rate (emi), energy use (ene), freight (fre).

' $z$ ' on front of a variable indicates, inverse of the variable. 
Table 4. Summary of the composite Lisbon development strategy indices and LSI components, $\mathrm{n}=306$ obs.

\begin{tabular}{|c|c|c|c|c|c|}
\hline Variable definition & Mean & Median & Std Dev & Minimum & Maximum \\
\hline \multicolumn{6}{|l|}{ A. LSI components: } \\
\hline geneco general economics & 0.854 & 0.939 & 0.521 & 0.000 & 2.000 \\
\hline employ employment & 0.923 & 0.869 & 0.491 & 0.056 & 2.000 \\
\hline inores innovation research & 1.014 & 1.015 & 0.335 & 0.147 & 1.899 \\
\hline ecoref economic reform & 1.040 & 0.988 & 0.396 & 0.081 & 1.977 \\
\hline soccoh social cohesion & 1.742 & 1.774 & 0.546 & 0.528 & 2.822 \\
\hline enviro environment & 1.755 & 1.768 & 0.336 & 0.830 & 2.571 \\
\hline \multicolumn{6}{|l|}{ B. Composite indices: } \\
\hline Lisbon structural index & 7.329 & 7.259 & 1.335 & 4.220 & 10.089 \\
\hline principal comp. type 1 & 1.948 & 2.174 & 0.602 & -0.000 & 2.912 \\
\hline principal comp. type 2 & 1.219 & 1.188 & 0.612 & -0.000 & 2.455 \\
\hline
\end{tabular}

Table 5. Pearson correlation matrix of normalized indicators, $n=306$ obs.

\begin{tabular}{|c|c|c|c|c|c|c|c|c|c|c|c|c|c|c|}
\hline & igdp & ilab & iemp & iold & iedu & iexp & iinv & ipri & ipov & iune & idis & iemi & iene & ifre \\
\hline igdp & 1.00 & & & & & & & & & & & & & \\
\hline ilab & $0.90 a$ & 1.00 & & & & & & & & & & & & \\
\hline iemp & $0.52 a$ & $0.34 a$ & 1.00 & & & & & & & & & & & \\
\hline iold & $0.23 a$ & $0.09 c$ & $0.67 a$ & 1.00 & & & & & & & & & & \\
\hline iedu & $-0.18 a$ & $-0.15 a$ & $0.17 a$ & 0.05 & 1.00 & & & & & & & & & \\
\hline iexp & $0.64 a$ & $0.60 \mathrm{a}$ & $0.49 a$ & $0.38 a$ & -0.06 & 1.00 & & & & & & & & \\
\hline iinv & $-0.21 a$ & $-0.25 a$ & -0.00 & $-0.16 a$ & $0.12 b$ & $-0.26 a$ & 1.00 & & & & & & & \\
\hline ipri & $-0.77 a$ & $-0.80 a$ & $-0.53 a$ & $-0.38 a$ & 0.07 & $-0.70 a$ & $0.32 a$ & 1.00 & & & & & & \\
\hline ipov & $0.31 a$ & $0.22 a$ & $0.39 a$ & -0.00 & $0.20 \mathrm{a}$ & $0.52 a$ & $-0.09 c$ & $-0.25 a$ & 1.00 & & & & & \\
\hline iune & $0.53 a$ & $0.37 a$ & $0.70 a$ & $0.51 a$ & -0.05 & $0.39 a$ & -0.05 & $-0.45 a$ & $0.22 a$ & 1.00 & & & & \\
\hline idis & 0.03 & -0.02 & $0.32 a$ & $0.17 a$ & $0.19 a$ & $0.16 a$ & 0.03 & -0.00 & $0.21 a$ & $0.16 a$ & 1.00 & & & \\
\hline iemi & $-0.46 a$ & $-0.51 a$ & $-0.16 a$ & $-0.24 a$ & $0.31 a$ & $-0.30 a$ & $0.10 \mathrm{c}$ & $0.44 a$ & 0.08 & $-0.34 a$ & -0.05 & 1.00 & & \\
\hline iene & $0.65 a$ & $0.74 \mathrm{a}$ & $0.29 a$ & $0.20 a$ & $-0.18 a$ & $0.52 a$ & $-0.10 c$ & $-0.69 a$ & $0.10 c$ & $0.45 a$ & 0.05 & $-0.67 a$ & 1.00 & \\
\hline ifre & -0.035 & -0.01 & -0.01 & $-0.16 a$ & 0.07 & $0.09 c$ & 0.02 & 0.01 & $0.21 a$ & -0.07 & 0.02 & $0.17 \mathrm{a}$ & -0.08 & 1.00 \\
\hline
\end{tabular}

note: less than $1 \%$ (a), 1-5\% (b) and 5-10\%(c) levels of significance.

Abbreviations: GDP per capita (gdp), labour productivity (lab), employment rate (emp) old age employment rate (old),

Education enrolment (edu), R\&D expenditure (R\&D), business investment (inv), prices (pri), risk at poverty (pov), Unemployment rate (une), regional employment distribution (dis), emission rate (emi), energy use (ene), freight (fre).

' $i$ ' on front of a variable indicates normalized variable. 
Table 6. Pearson correlation matrix of different composite indices and index components, $\mathrm{n}=306$ obs.

\begin{tabular}{|c|c|c|c|c|c|c|c|c|c|c|}
\hline & year & geneco & employ & inores & ecoref & soccoh & enviro & LSI & PC1 & PC2 \\
\hline year & 1.000 & & & & & & & & & \\
\hline geneco & -0.055 & 1.000 & & & & & & & & \\
\hline employ & 0.043 & $0.318 a$ & 1.000 & & & & & & & \\
\hline inores & -0.016 & $0.356 a$ & $0.442 \mathrm{a}$ & 1.000 & & & & & & \\
\hline ecoref & 0.077 & $-0.676 a$ & $-0.387 a$ & $-0.379 a$ & 1.000 & & & & & \\
\hline soccoh & 0.088 & $0.351 a$ & $0.562 \mathrm{a}$ & $0.505 a$ & $-0.256 a$ & 1.000 & & & & \\
\hline enviro & $0.525 a$ & $0.110 \mathrm{~b}$ & -0.057 & $0.280 a$ & -0.082 & $0.139 a$ & 1.000 & & & \\
\hline struct & $0.182 a$ & $0.567 a$ & $0.704 a$ & $0.717 a$ & $-0.330 a$ & $0.838 a$ & $0.376 a$ & 1.000 & & \\
\hline princil & 0.067 & $0.819 a$ & $0.479 a$ & $0.197 a$ & $-0.530 a$ & $0.357 a$ & -0.053 & $0.520 a$ & 1.000 & \\
\hline princi2 & $0.095 c$ & $0.741 \mathrm{a}$ & $0.659 a$ & $0.721 \mathrm{a}$ & $-0.534 a$ & $0.768 a$ & $0.227 a$ & $0.925 a$ & $0.687 a$ & 1.000 \\
\hline
\end{tabular}

note: less than $1 \%$ (a), 1-5\% (b) and 5-10\%(c) levels of significance.

Abbreviations: general economics (geneco), employment (employ), innovation research (inores), economic reform (ecoref),

Social cohesion (soccoh), environment (enviro), structural index (struct), principal component index 1 (princi1), Principal component index 2 (princi2).

Table 7. Pearson correlation matrix of social coherence and economic performance, $\mathrm{n}=306$ obs.

\begin{tabular}{|c|c|c|c|c|c|c|c|c|c|}
\hline & \multirow{2}{*}{$\begin{array}{r}\text { year } \\
1.000\end{array}$} & \multirow{2}{*}{ gdp } & $1 a b$ & dgdp & dlab & igdp & \multirow[t]{2}{*}{ ilab } & geneco & \multirow[t]{2}{*}{ soccoh } \\
\hline year & & & & & & & & & \\
\hline gdp & 0.031 & 1.000 & & & & & & & \\
\hline lab & 0.031 & $0.910 a$ & 1.000 & & & & & & \\
\hline dgdp & 0.029 & $-0.116 b$ & $-0.107 c$ & 1.000 & & & & & \\
\hline dlab & 0.024 & $-0.264 a$ & $-0.298 a$ & $0.707 a$ & 1.000 & & & & \\
\hline igdp & -0.095 & $0.986 a$ & $0.901 a$ & $-0.117 b$ & $-0.261 a$ & 1.000 & & & \\
\hline ilab & -0.018 & $0.905 a$ & $0.995 a$ & $-0.116 b$ & $-0.305 a$ & $0.907 a$ & 1.000 & & \\
\hline geneco & -0.055 & $0.964 a$ & $0.974 a$ & $-0.119 b$ & $-0.291 a$ & $0.972 a$ & $0.980 a$ & 1.000 & \\
\hline soccoh & 0.088 & $0.444 a$ & $0.278 a$ & $-0.133 b$ & $-0.151 \mathrm{a}$ & $0.427 \mathrm{a}$ & $0.271 \mathrm{a}$ & $0.351 a$ & 1.000 \\
\hline
\end{tabular}

note: less than $1 \%$ (a), 1-5\% (b) and 5-10\%(c) levels of significance.

Abbreviations: GDP per capita (gdp), labour productivity (lab), \% change in GDP per capita (dgdp), \% change in labour

productivity (dlab), Normalized GDP per capita (igdp), normalized labour productivity (ilab),

general economics (geneco), social cohesion (soccoh). 
Table 8. mean normalized indicators by year, country and country groups, $\mathrm{n}=306$ obs.

\begin{tabular}{|c|c|c|c|c|c|c|c|c|c|c|c|c|c|c|}
\hline country & igdp & ilab & ipri & ipov & iemp & iold & iune & idis & iedu & $i \exp$ & iinv & ifre & iemi & iene \\
\hline \multicolumn{15}{|c|}{ A. Mean by country } \\
\hline Sweden & 0.525 & 0.655 & 0.299 & 0.974 & 0.817 & 0.973 & 0.837 & 0.835 & 0.855 & 1.000 & 0.107 & 0.509 & 0.411 & 0.939 \\
\hline Norway & 0.686 & 0.801 & 0.218 & 0.562 & 1.000 & 0.989 & 0.998 & 0.995 & 0.983 & 0.395 & 0.327 & 0.276 & 0.364 & 0.962 \\
\hline USA & 0.743 & 0.913 & 0.468 & 0.562 & 0.858 & 0.819 & 0.992 & 0.255 & 0.652 & 0.660 & 0.383 & 0.521 & 0.325 & 0.885 \\
\hline Austria & 0.580 & 0.663 & 0.444 & 0.732 & 0.701 & 0.198 & 0.919 & 0.979 & 0.793 & 0.450 & 0.571 & 0.399 & 0.386 & 0.986 \\
\hline Netherla & 0.551 & 0.646 & 0.461 & 0.837 & 0.780 & 0.356 & 0.870 & 0.989 & 0.571 & 0.476 & 0.423 & 0.475 & 0.388 & 0.954 \\
\hline Denmark & 0.574 & 0.642 & 0.240 & 0.882 & 0.933 & 0.747 & 0.905 & 0.255 & 0.671 & 0.530 & 0.423 & 0.559 & 0.351 & 0.993 \\
\hline Czech Rep & 0.242 & 0.260 & 0.911 & 1.000 & 0.622 & 0.392 & 0.744 & 0.767 & 0.954 & 0.247 & 0.867 & 0.494 & 0.626 & 0.565 \\
\hline Korea & 0.235 & 0.212 & 0.842 & 0.673 & 0.465 & 0.870 & 0.643 & 0.821 & 0.645 & 0.610 & 0.525 & 0.621 & 0.385 & 0.968 \\
\hline Finland & 0.493 & 0.694 & 0.303 & 0.895 & 0.602 & 0.450 & 0.673 & 0.699 & 0.833 & 0.770 & 0.288 & 0.509 & 0.387 & 0.919 \\
\hline Luxembour & 1.000 & 1.000 & 0.456 & 0.771 & 0.460 & 0.128 & 0.957 & 0.255 & 0.446 & 0.406 & 0.377 & 0.605 & 0.676 & 0.957 \\
\hline Germany & 0.507 & 0.646 & 0.424 & 0.778 & 0.579 & 0.394 & 0.603 & 0.764 & 0.636 & 0.596 & 0.474 & 0.455 & 0.584 & 0.974 \\
\hline UK & 0.509 & 0.656 & 0.459 & 0.399 & 0.777 & 0.663 & 0.832 & 0.686 & 0.592 & 0.451 & 0.226 & 0.517 & 0.523 & 0.943 \\
\hline Japan & 0.539 & 0.577 & 0.004 & 0.562 & 0.723 & 0.933 & 0.928 & 0.255 & 0.652 & 0.749 & 0.383 & 0.488 & 0.352 & 1.000 \\
\hline France & 0.509 & 0.810 & 0.425 & 0.582 & 0.455 & 0.239 & 0.628 & 0.700 & 0.724 & 0.551 & 0.289 & 0.474 & 0.411 & 0.962 \\
\hline Belgium & 0.529 & 0.850 & 0.452 & 0.660 & 0.360 & 0.099 & 0.565 & 0.615 & 0.727 & 0.484 & 0.455 & 0.545 & 0.390 & 0.941 \\
\hline Slovenia & 0.269 & 0.352 & 0.700 & 0.837 & 0.504 & 0.054 & 0.687 & 0.255 & 0.860 & 0.336 & 0.679 & 0.516 & 0.466 & 0.876 \\
\hline Hungary & 0.157 & 0.283 & 0.897 & 0.837 & 0.231 & 0.026 & 0.662 & 0.544 & 0.772 & 0.149 & 0.499 & 0.496 & 0.689 & 0.733 \\
\hline Ireland & 0.534 & 0.800 & 0.414 & 0.307 & 0.466 & 0.514 & 0.664 & 0.255 & 0.753 & 0.269 & 0.481 & 0.324 & 0.214 & 0.967 \\
\hline Romania & 0.003 & 0.002 & 0.960 & 0.458 & 0.507 & 0.602 & 0.736 & 0.862 & 0.708 & 0.050 & 0.351 & 0.562 & 0.818 & 0.308 \\
\hline Slovakia & 0.126 & 0.204 & 0.945 & 0.235 & 0.371 & 0.060 & 0.112 & 0.606 & 0.991 & 0.144 & 0.941 & 0.837 & 0.674 & 0.553 \\
\hline Cyprus & 0.337 & 0.426 & 0.611 & 0.529 & 0.641 & 0.640 & 0.914 & 0.255 & 0.800 & 0.000 & 0.223 & 0.487 & 0.009 & 0.912 \\
\hline Portugal & 0.284 & 0.334 & 0.695 & 0.235 & 0.650 & 0.641 & 0.801 & 0.894 & 0.064 & 0.131 & 0.662 & 0.304 & 0.138 & 0.937 \\
\hline Iceland & 0.574 & 0.696 & 0.287 & 0.562 & 0.475 & 0.368 & 0.614 & 0.255 & 0.129 & 0.589 & 0.383 & 0.466 & 0.396 & 0.821 \\
\hline Poland & 0.105 & 0.168 & 0.865 & 0.516 & 0.280 & 0.226 & 0.334 & 0.754 & 0.848 & 0.110 & 0.372 & 0.569 & 0.678 & 0.671 \\
\hline Greece & 0.275 & 0.516 & 0.620 & 0.255 & 0.267 & 0.433 & 0.484 & 0.821 & 0.708 & 0.095 & 0.470 & 0.206 & 0.242 & 0.926 \\
\hline Estonia & 0.090 & 0.105 & 0.849 & 0.412 & 0.513 & 0.644 & 0.554 & 0.255 & 0.777 & 0.110 & 0.744 & 0.038 & 0.892 & 0.332 \\
\hline Croatia & 0.088 & 0.608 & 0.503 & 0.562 & 0.189 & 0.183 & 0.189 & 0.255 & 0.934 & 0.241 & 0.383 & 0.468 & 0.609 & 0.950 \\
\hline Spain & 0.375 & 0.630 & 0.610 & 0.366 & 0.191 & 0.355 & 0.360 & 0.465 & 0.429 & 0.183 & 0.600 & 0.361 & 0.189 & 0.946 \\
\hline Latvia & 0.048 & 0.060 & 0.887 & 0.529 & 0.401 & 0.388 & 0.309 & 0.255 & 0.659 & 0.044 & 0.572 & 0.254 & 0.971 & 0.644 \\
\hline Lithuania & 0.072 & 0.068 & 0.921 & 0.471 & 0.447 & 0.446 & 0.357 & 0.255 & 0.766 & 0.087 & 0.459 & 0.450 & 0.891 & 0.333 \\
\hline Italy & 0.497 & 0.777 & 0.538 & 0.359 & 0.180 & 0.181 & 0.373 & 0.000 & 0.462 & 0.227 & 0.336 & 0.447 & 0.374 & 0.966 \\
\hline Malta & 0.292 & 0.537 & 0.716 & 0.588 & 0.218 & 0.201 & 0.609 & 0.255 & 0.005 & 0.450 & 0.292 & 0.468 & 0.149 & 0.904 \\
\hline Turkey & 0.020 & 0.076 & 0.876 & 0.000 & 0.010 & 0.344 & 0.873 & 0.255 & 0.652 & 0.085 & 0.402 & 0.370 & 0.500 & 0.814 \\
\hline Bulgaria & 0.010 & 0.010 & 0.997 & 0.647 & 0.093 & 0.064 & 0.055 & 0.524 & 0.653 & 0.077 & 0.101 & 0.739 & 0.870 & 0.000 \\
\hline \multicolumn{15}{|c|}{ B. Mean by country group } \\
\hline EU12 & 0.512 & 0.692 & 0.483 & 0.536 & 0.508 & 0.396 & 0.670 & 0.558 & 0.565 & 0.367 & 0.435 & 0.439 & 0.373 & 0.955 \\
\hline EU15 & 0.516 & 0.688 & 0.456 & 0.602 & 0.548 & 0.425 & 0.698 & 0.614 & 0.618 & 0.441 & 0.412 & 0.446 & 0.378 & 0.954 \\
\hline EU25 & 0.379 & 0.511 & 0.606 & 0.599 & 0.498 & 0.378 & 0.630 & 0.536 & 0.668 & 0.332 & 0.473 & 0.452 & 0.468 & 0.833 \\
\hline
\end{tabular}




\begin{tabular}{|c|c|c|c|c|c|c|c|c|c|c|c|c|c|c|}
\hline Japan & 0.539 & 0.577 & 0.004 & 0.562 & 0.723 & 0.933 & 0.928 & 0.255 & 0.652 & 0.749 & 0.383 & 0.488 & 0.352 & 1.000 \\
\hline Korea & 0.235 & 0.212 & 0.842 & 0.673 & 0.465 & 0.870 & 0.643 & 0.821 & 0.645 & 0.610 & 0.525 & 0.621 & 0.385 & 0.968 \\
\hline Other & 0.230 & 0.365 & 0.640 & 0.465 & 0.379 & 0.425 & 0.577 & 0.524 & 0.677 & 0.240 & 0.325 & 0.480 & 0.593 & 0.642 \\
\hline USA & 0.743 & 0.913 & 0.468 & 0.562 & 0.858 & 0.819 & 0.992 & 0.255 & 0.652 & 0.660 & 0.383 & 0.521 & 0.325 & 0.885 \\
\hline \multicolumn{15}{|c|}{ C. Mean by year } \\
\hline 1995 & 0.395 & 0.502 & 0.644 & 0.545 & 0.471 & 0.438 & 0.618 & 0.534 & 0.651 & 0.370 & 0.372 & 0.000 & 0.409 & 0.805 \\
\hline 1996 & 0.403 & 0.516 & 0.560 & 0.566 & 0.458 & 0.440 & 0.587 & 0.534 & 0.643 & 0.354 & 0.328 & 0.406 & 0.418 & 0.819 \\
\hline 1997 & 0.393 & 0.505 & 0.576 & 0.571 & 0.455 & 0.447 & 0.578 & 0.534 & 0.657 & 0.361 & 0.454 & 0.438 & 0.404 & 0.820 \\
\hline 1998 & 0.372 & 0.487 & 0.547 & 0.587 & 0.468 & 0.452 & 0.590 & 0.534 & 0.691 & 0.361 & 0.415 & 0.572 & 0.464 & 0.818 \\
\hline 1999 & 0.350 & 0.462 & 0.626 & 0.581 & 0.477 & 0.436 & 0.619 & 0.534 & 0.668 & 0.363 & 0.499 & 0.643 & 0.474 & 0.807 \\
\hline 2000 & 0.338 & 0.459 & 0.680 & 0.585 & 0.484 & 0.423 & 0.637 & 0.523 & 0.672 & 0.321 & 0.547 & 0.503 & 0.500 & 0.809 \\
\hline 2001 & 0.344 & 0.488 & 0.638 & 0.580 & 0.513 & 0.405 & 0.703 & 0.518 & 0.662 & 0.330 & 0.411 & 0.531 & 0.500 & 0.808 \\
\hline 2002 & 0.342 & 0.492 & 0.581 & 0.585 & 0.534 & 0.408 & 0.723 & 0.498 & 0.691 & 0.324 & 0.543 & 0.520 & 0.494 & 0.802 \\
\hline 2003 & 0.338 & 0.503 & 0.521 & 0.583 & 0.576 & 0.421 & 0.712 & 0.526 & 0.676 & 0.328 & 0.421 & 0.572 & 0.659 & 0.802 \\
\hline
\end{tabular}


Table 9. Mean composite indices and their components by year, country and country groups, $\mathrm{n}=306$ obs.

\begin{tabular}{|c|c|c|c|c|c|c|c|c|c|c|c|c|}
\hline country & geneco & employ & inores & ecoref & soccoh & enviro & Rank1 & LSI & Rank2 & PC1 & Rank3 & PC2 \\
\hline \multicolumn{13}{|c|}{ A. Mean by country } \\
\hline Sweden & 1.181 & 1.790 & 1.855 & 0.406 & 2.645 & 1.860 & 1 & 9.736 & 18 & 2.185 & 2 & 2.331 \\
\hline Norway & 1.487 & 1.989 & 1.378 & 0.545 & 2.555 & 1.602 & 2 & 9.557 & 1 & 2.681 & 1 & 2.372 \\
\hline USA & 1.656 & 1.677 & 1.312 & 0.851 & 1.809 & 1.732 & 3 & 9.037 & 2 & 2.601 & 7 & 1.887 \\
\hline Austria & 1.243 & 0.899 & 1.242 & 1.014 & 2.630 & 1.771 & 4 & 8.800 & 8 & 2.421 & 4 & 2.039 \\
\hline Netherland & d 1.197 & 1.136 & 1.047 & 0.884 & 2.696 & 1.818 & 5 & 8.778 & 11 & 2.303 & 5 & 2.003 \\
\hline Denmark & 1.216 & 1.680 & 1.201 & 0.663 & 2.042 & 1.903 & 6 & 8.705 & 7 & 2.440 & 3 & 2.053 \\
\hline Czech Rep. & .0 .503 & 1.015 & 1.202 & 1.778 & 2.511 & 1.685 & 7 & 8.692 & 27 & 1.493 & 11 & 1.609 \\
\hline Korea & 0.447 & 1.334 & 1.256 & 1.367 & 2.138 & 1.974 & 8 & 8.516 & 23 & 1.796 & 16 & 1.332 \\
\hline Finland & 1.186 & 1.052 & 1.603 & 0.590 & 2.267 & 1.814 & 9 & 8.514 & 21 & 2.153 & 6 & 1.916 \\
\hline Luxembourg & g 2.000 & 0.587 & 0.853 & 0.834 & 1.983 & 2.237 & 10 & 8.494 & 6 & 2.450 & 10 & 1.642 \\
\hline Germany & 1.153 & 0.972 & 1.232 & 0.898 & 2.145 & 2.013 & 11 & 8.413 & 20 & 2.154 & 9 & 1.690 \\
\hline UK & 1.166 & 1.440 & 1.043 & 0.686 & 1.916 & 1.983 & 11 & 8.233 & 12 & 2.224 & 14 & 1.378 \\
\hline Japan & 1.115 & 1.656 & 1.401 & 0.387 & 1.745 & 1.839 & 13 & 8.144 & 4 & 2.597 & 8 & 1.798 \\
\hline France & 1.319 & 0.694 & 1.275 & 0.714 & 1.909 & 1.847 & 14 & 7.758 & 13 & 2.216 & 12 & 1.453 \\
\hline Belgium & 1.379 & 0.460 & 1.211 & 0.907 & 1.840 & 1.876 & 15 & 7.672 & 17 & 2.197 & 13 & 1.432 \\
\hline Slovenia & 0.620 & 0.558 & 1.196 & 1.378 & 1.778 & 1.858 & 16 & 7.388 & 22 & 1.828 & 15 & 1.338 \\
\hline Hungary & 0.439 & 0.258 & 0.922 & 1.397 & 2.043 & 1.918 & 17 & 6.976 & 28 & 1.371 & 24 & 0.856 \\
\hline Ireland & 1.335 & 0.980 & 1.021 & 0.895 & 1.226 & 1.505 & 18 & 6.962 & 3 & 2.600 & 17 & 1.280 \\
\hline Romania & 0.005 & 1.109 & 0.759 & 1.311 & 2.055 & 1.687 & 19 & 6.926 & 33 & 0.942 & 30 & 0.525 \\
\hline Slovakia & 0.330 & 0.431 & 1.135 & 1.886 & 0.953 & 2.064 & 20 & 6.799 & 31 & 1.117 & 26 & 0.714 \\
\hline Cyprus & 0.763 & 1.280 & 0.800 & 0.835 & 1.698 & 1.409 & 21 & 6.785 & 15 & 2.209 & 19 & 1.089 \\
\hline Portugal & 0.618 & 1.291 & 0.195 & 1.358 & 1.931 & 1.378 & 22 & 6.770 & 5 & 2.515 & 21 & 0.909 \\
\hline Iceland & 1.269 & 0.843 & 0.719 & 0.670 & 1.431 & 1.683 & 23 & 6.615 & 9 & 2.387 & 18 & 1.102 \\
\hline Poland & 0.273 & 0.506 & 0.958 & 1.237 & 1.605 & 1.918 & 24 & 6.497 & 30 & 1.149 & 28 & 0.646 \\
\hline Greece & 0.790 & 0.700 & 0.803 & 1.090 & 1.560 & 1.373 & 25 & 6.316 & 14 & 2.211 & 22 & 0.892 \\
\hline Estonia & 0.195 & 1.157 & 0.887 & 1.593 & 1.220 & 1.262 & 26 & 6.315 & 26 & 1.502 & 29 & 0.624 \\
\hline Croatia & 0.696 & 0.372 & 1.176 & 0.886 & 1.006 & 2.027 & 27 & 6.162 & 25 & 1.653 & 20 & 0.956 \\
\hline Spain & 1.005 & 0.546 & 0.612 & 1.210 & 1.191 & 1.496 & 28 & 6.059 & 10 & 2.329 & 25 & 0.843 \\
\hline Latvia & 0.108 & 0.789 & 0.703 & 1.458 & 1.093 & 1.870 & 29 & 6.022 & 29 & 1.246 & 32 & 0.400 \\
\hline Lithuania & 0.140 & 0.892 & 0.853 & 1.379 & 1.082 & 1.674 & 30 & 6.021 & 31 & 0.997 & 31 & 0.447 \\
\hline Italy & 1.274 & 0.362 & 0.689 & 0.874 & 0.733 & 1.786 & 31 & 5.718 & 16 & 2.206 & 23 & 0.869 \\
\hline Malta & 0.829 & 0.418 & 0.455 & 1.009 & 1.452 & 1.521 & 32 & 5.684 & 19 & 2.172 & 27 & 0.676 \\
\hline Turkey & 0.096 & 0.355 & 0.737 & 1.278 & 1.127 & 1.684 & 33 & 5.276 & 24 & 1.703 & 33 & 0.209 \\
\hline Bulgaria & 0.020 & 0.156 & 0.730 & 1.097 & 1.226 & 1.609 & 34 & 4.839 & 34 & 0.183 & 34 & 0.136 \\
\hline B. Mean by & country & group & & & & & & & & & & \\
\hline EU12 & 1.204 & 0.904 & 0.932 & 0.918 & 1.764 & 1.768 & & 7.490 & & 2.320 & & 1.370 \\
\hline EU15 & 1.204 & 0.973 & 1.059 & 0.868 & 1.914 & 1.777 & & 7.795 & & 2.307 & & 1.515 \\
\hline EU25 & 0.890 & 0.876 & 1.000 & 1.079 & 1.766 & 1.754 & & 7.364 & & 1.988 & & 1.245 \\
\hline
\end{tabular}




\begin{tabular}{|c|c|c|c|c|c|c|c|c|c|}
\hline \multicolumn{10}{|c|}{8.144} \\
\hline Korea & 0.447 & 1.334 & 1.256 & 1.367 & 2.138 & 1.974 & 8.516 & 1.796 & 1.332 \\
\hline Other & 0.596 & 0.804 & 0.916 & 0.964 & 1.567 & 1.715 & 6.562 & 1.591 & 0.883 \\
\hline USA & 1.656 & 1.677 & 1.312 & 0.851 & 1.809 & 1.732 & 9.037 & 2.601 & 1.887 \\
\hline \multicolumn{10}{|c|}{ C. Mean by year } \\
\hline 1995 & 0.897 & 0.908 & 1.021 & 1.016 & 1.697 & 1.214 & 6.752 & 1.870 & 1.112 \\
\hline 1996 & 0.919 & 0.899 & 0.997 & 0.888 & 1.686 & 1.643 & 7.032 & 1.890 & 1.135 \\
\hline 1997 & 0.898 & 0.903 & 1.018 & 1.030 & 1.682 & 1.662 & 7.194 & 1.929 & 1.178 \\
\hline 1998 & 0.860 & 0.921 & 1.051 & 0.962 & 1.710 & 1.854 & 7.358 & 1.938 & 1.220 \\
\hline 1999 & 0.812 & 0.913 & 1.031 & 1.125 & 1.734 & 1.924 & 7.539 & 1.965 & 1.228 \\
\hline 2000 & 0.798 & 0.908 & 0.993 & 1.226 & 1.745 & 1.811 & 7.480 & 1.978 & 1.264 \\
\hline 2001 & 0.833 & 0.917 & 0.992 & 1.049 & 1.800 & 1.838 & 7.430 & 1.982 & 1.269 \\
\hline 2002 & 0.834 & 0.942 & 1.015 & 1.123 & 1.806 & 1.816 & 7.537 & 1.975 & 1.274 \\
\hline 2003 & 0.841 & 0.997 & 1.004 & 0.942 & 1.821 & 2.033 & 7.637 & 2.006 & 1.291 \\
\hline
\end{tabular}

Abbreviations: general economics (geneco), employment (employ), innovation research (inores), economic reform (ecoref),

Social cohesion (soccoh), environment (enviro), Lisbon structural index (LSI), principal component1/2 (PC1/PC2). 
Table 10. Percent changes in indices and index components by country, country groups and over time, $\mathrm{n}=306$.

\begin{tabular}{|c|c|c|c|c|c|c|c|c|c|}
\hline country & dgeneco & demploy & dinores & decoref & dsoccoh & denviro & $\mathrm{dLSI}$ & $\mathrm{dPC1}$ & $\mathrm{dPC2}$ \\
\hline \multicolumn{10}{|c|}{ A. Mean changes by country } \\
\hline Austria & -2.28 & -0.46 & 1.24 & 2.22 & -0.05 & 8.23 & 1.23 & -0.12 & 0.32 \\
\hline Belgium & -1.51 & 4.58 & 0.88 & -0.07 & 2.89 & 9.90 & 2.47 & -0.53 & 2.33 \\
\hline Bulgaria & 14.60 & 21.08 & -1.48 & 2.03 & 3.44 & 11.16 & 3.90 & -9.50 & 28.06 \\
\hline Croatia & 0.08 & -2.10 & -1.04 & -0.34 & 2.13 & 4.17 & 0.90 & 0.99 & 1.79 \\
\hline Cyprus & -3.23 & 1.00 & -0.61 & -3.55 & 0.33 & 6.53 & 0.15 & 0.73 & 0.02 \\
\hline Czech Rep. & -1.15 & -0.11 & 0.14 & -1.64 & -0.96 & 7.50 & 0.21 & -0.02 & -0.04 \\
\hline Denmark & -1.42 & 1.98 & -1.67 & 1.98 & 0.70 & 11.38 & 1.88 & -0.38 & 0.51 \\
\hline Estonia & 12.77 & -0.20 & -0.69 & 2.25 & 0.14 & -0.23 & 0.53 & 10.51 & 4.92 \\
\hline Finland & -0.79 & 5.94 & 1.60 & 3.13 & 0.61 & 8.03 & 2.42 & 1.06 & 0.87 \\
\hline France & -1.92 & 3.77 & -1.58 & 1.73 & 1.55 & 7.61 & 1.51 & -0.19 & 1.04 \\
\hline Germany & -2.71 & 0.08 & -2.42 & -3.16 & 0.78 & 7.28 & 0.38 & -1.27 & 0.62 \\
\hline Greece & 1.28 & 1.46 & 2.11 & 5.64 & 1.57 & 4.59 & 2.62 & 2.46 & 5.07 \\
\hline Hungary & 2.38 & 16.22 & 1.78 & 0.87 & 2.28 & 5.39 & 3.06 & 3.13 & 5.85 \\
\hline Iceland & -2.35 & 1.79 & 7.07 & -4.25 & 1.70 & 5.77 & 1.33 & 0.52 & 4.01 \\
\hline Ireland & 1.70 & 7.42 & 0.75 & 0.91 & 5.99 & 6.12 & 3.50 & 4.18 & 5.82 \\
\hline Italy & -2.96 & 4.64 & 2.96 & -1.00 & 6.09 & 8.89 & 2.59 & -0.32 & 2.50 \\
\hline Japan & -2.09 & -0.59 & -0.55 & 5.08 & 0.29 & 9.24 & 1.32 & -1.40 & 0.08 \\
\hline Korea & 2.79 & -1.45 & -1.23 & -4.03 & -0.63 & 12.19 & 0.66 & -1.52 & 0.36 \\
\hline Latvia & 16.77 & 3.10 & -2.59 & 7.91 & 4.25 & 1.28 & 3.00 & 11.34 & 15.36 \\
\hline Lithuania & 16.88 & 0.90 & -0.16 & -0.43 & 2.08 & 6.04 & 1.49 & 7.59 & 8.52 \\
\hline Luxembourg & 0.00 & 4.39 & 4.71 & -0.91 & 0.06 & 8.34 & 1.79 & 0.08 & 2.44 \\
\hline Malta & -2.74 & 0.77 & -2.74 & -0.21 & 1.26 & 9.82 & 1.30 & 0.14 & 3.07 \\
\hline Netherlands & s -1.80 & 7.03 & -0.88 & -0.98 & 0.93 & 9.44 & 2.19 & -0.28 & 1.56 \\
\hline Norway & 0.66 & -0.24 & -0.21 & -14.27 & 0.62 & 6.05 & 0.32 & 0.75 & 0.58 \\
\hline Poland & 5.07 & -11.14 & -0.11 & 1.42 & -5.91 & 7.10 & -0.49 & -0.12 & 1.17 \\
\hline Portugal & -1.63 & 2.33 & 2.87 & 0.64 & 1.78 & 6.90 & 1.98 & 1.11 & 3.52 \\
\hline Romania & 39.17 & -6.39 & -3.96 & 3.69 & -1.10 & 7.27 & -0.02 & 3.78 & -1.37 \\
\hline Slovakia & 3.72 & -1.83 & -1.72 & 0.82 & -2.98 & 10.62 & 1.40 & -1.43 & 2.26 \\
\hline Slovenia & 1.17 & 1.87 & -0.17 & 1.61 & 0.66 & 8.20 & 2.12 & 0.23 & 1.26 \\
\hline Spain & -0.57 & 13.75 & 1.62 & 3.80 & 9.45 & 7.17 & 4.75 & 3.48 & 6.34 \\
\hline Sweden & -1.82 & 1.38 & -0.43 & 4.80 & 0.44 & 8.07 & 1.05 & 0.43 & 0.78 \\
\hline Turkey & 5.15 & -8.32 & 0.87 & -0.95 & -0.76 & 7.00 & 1.12 & -0.40 & 1.45 \\
\hline UK & -0.23 & 2.19 & 1.28 & -2.07 & 3.32 & 7.94 & 2.55 & -0.03 & 3.52 \\
\hline USA & -0.86 & 0.30 & -0.86 & -1.79 & 0.88 & 10.04 & 1.22 & -0.45 & 1.58 \\
\hline \multicolumn{10}{|c|}{ B. Mean changes by country group } \\
\hline EU25 & 1.40 & 2.84 & 0.25 & 1.03 & 1.49 & 7.29 & 1.83 & 1.67 & 3.18 \\
\hline Japan & -2.09 & -0.59 & -0.55 & 5.08 & 0.29 & 9.24 & 1.32 & -1.40 & 0.08 \\
\hline Korea & 2.79 & -1.45 & -1.23 & -4.03 & -0.63 & 12.19 & 0.66 & -1.52 & 0.36 \\
\hline
\end{tabular}




\begin{tabular}{lrrrrrrrrr} 
Other & 9.55 & 0.97 & 0.21 & -2.35 & 1.01 & 6.90 & 1.26 & -0.64 & 5.75 \\
USA & -0.86 & 0.30 & -0.86 & -1.79 & 0.88 & 10.04 & 1.22 & -0.45 & 1.58 \\
$\begin{array}{l}\text { C. Mean } \\
\text { changes by }\end{array}$ & \multicolumn{1}{l}{ year } & & & & & & & & \\
1996 & 4.13 & -2.35 & -1.21 & -15.23 & -0.86 & 36.21 & 4.30 & 0.60 & 4.35 \\
1997 & 2.15 & -0.55 & 2.39 & 21.69 & -0.34 & 1.33 & 2.36 & 2.60 & 4.51 \\
1998 & -4.55 & 4.33 & 3.48 & -7.72 & 2.83 & 11.93 & 2.51 & -0.27 & 4.93 \\
1999 & -1.07 & -1.40 & -2.06 & 21.27 & 1.99 & 4.02 & 2.46 & 1.26 & 0.70 \\
2000 & 4.20 & -1.79 & -2.82 & 10.43 & 0.83 & -5.68 & -0.72 & 0.57 & 5.03 \\
2001 & 3.54 & 3.24 & 0.29 & -16.54 & 3.73 & 1.50 & -0.59 & 0.19 & 1.49 \\
2002 & 5.88 & 7.12 & 2.44 & 8.97 & 0.83 & -1.31 & 1.61 & -0.03 & 0.00 \\
2003 & 7.40 & 9.08 & -1.39 & -20.31 & 1.32 & 11.99 & 1.36 & 3.20 & 6.32
\end{tabular}

Abbreviations: general economics (geneco), employment (employ), innovation research (inores), economic reform (ecoref), Social cohesion (soccoh), environment (enviro), Lisbon structural index (LSI), principal component1/2 (PC1/PC2. ' $d$ ' on front of a variable indicates percentage change. 
Figure 1. Lisbon Development Strategy Index (LIS) components.

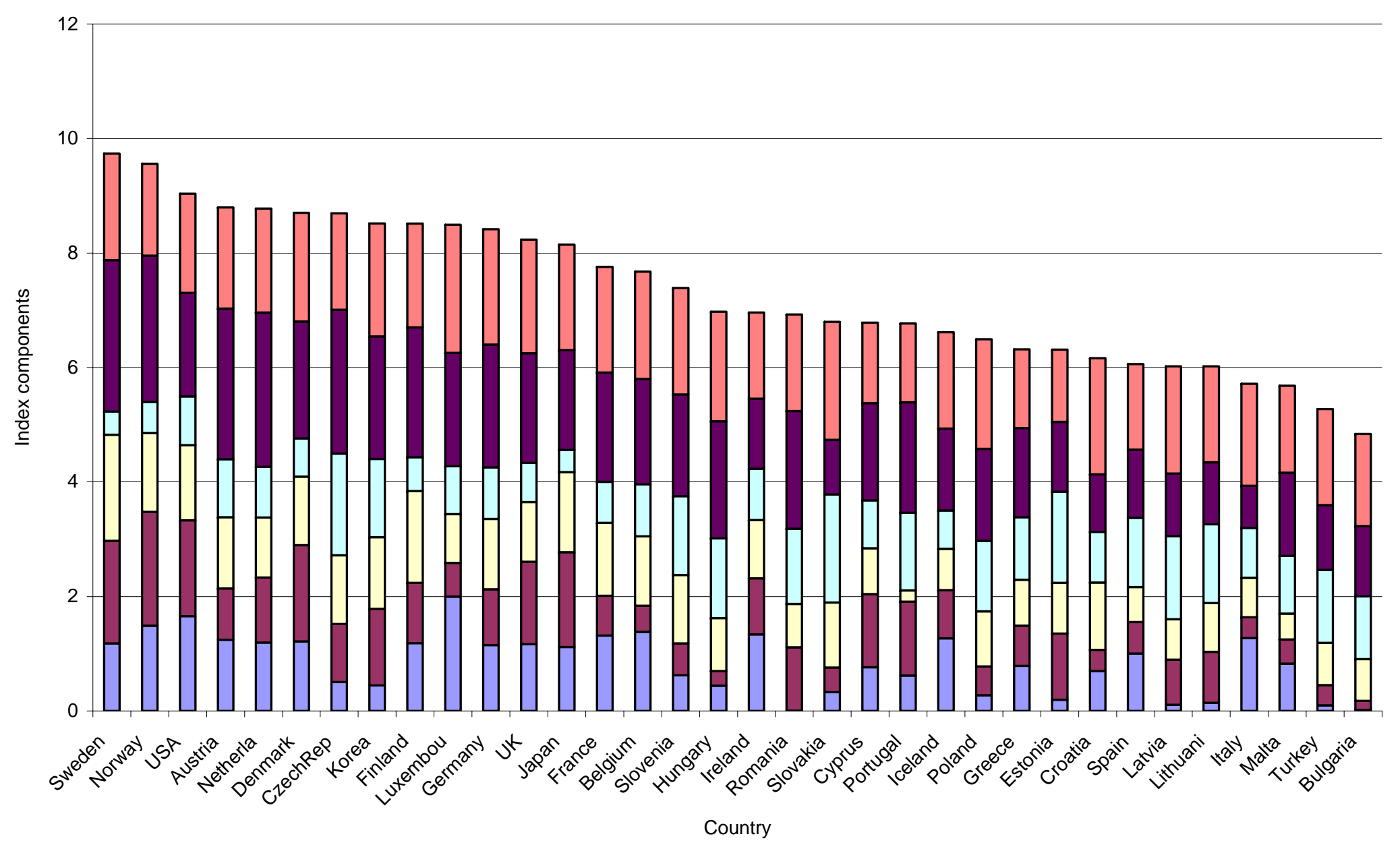

$\square$ geneco $\square$ employ $\square$ inores $\square$ ecoref $\square$ soccoh $\square$ enviro 
Figure 2. Lisbon development strategy index (LSI), principal component index (PC1) and accounting for negative effects (PC2) normalized at USA level.

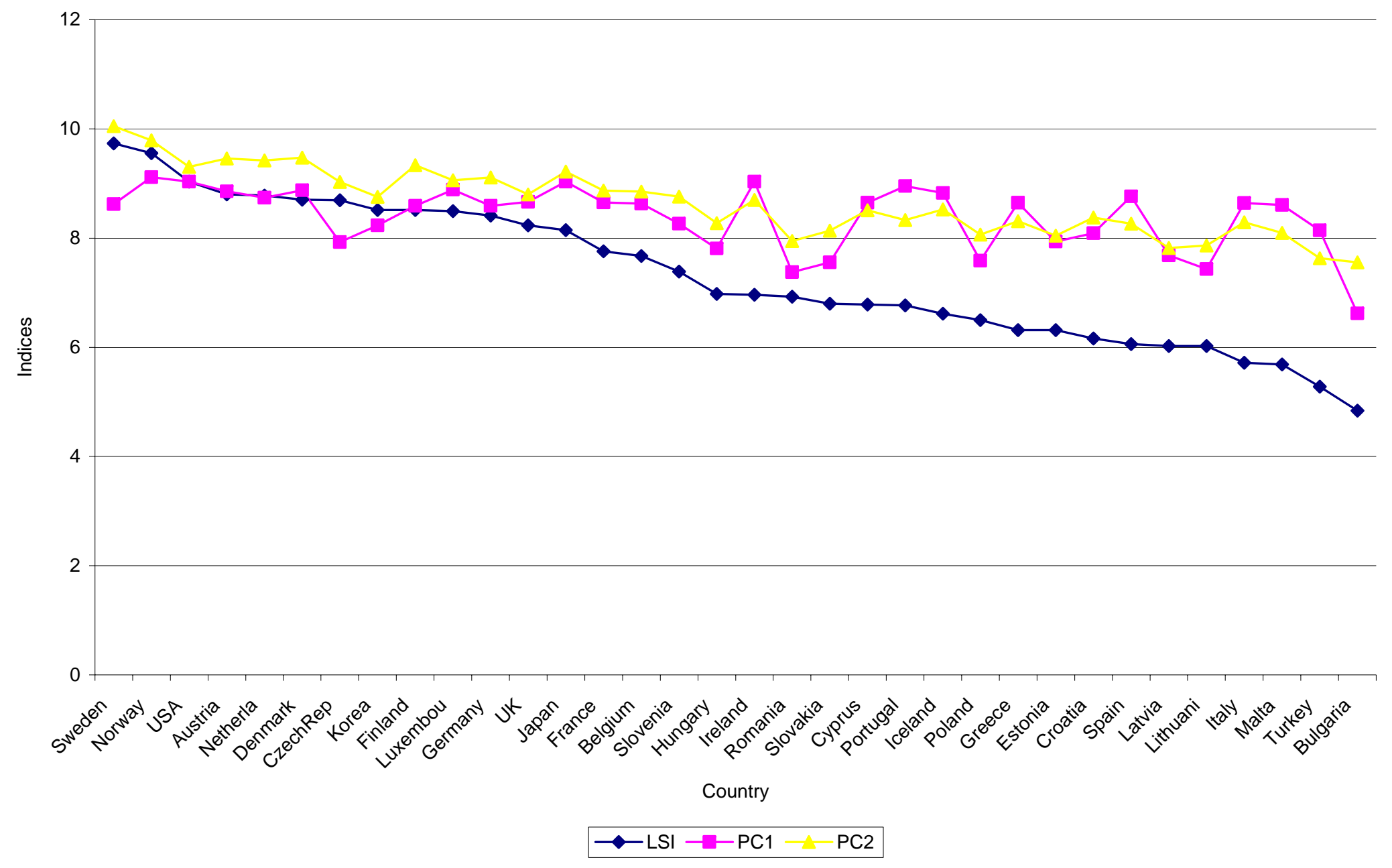


Figure 3. Lisbon Devlopment Strategy Index (LSI) components.

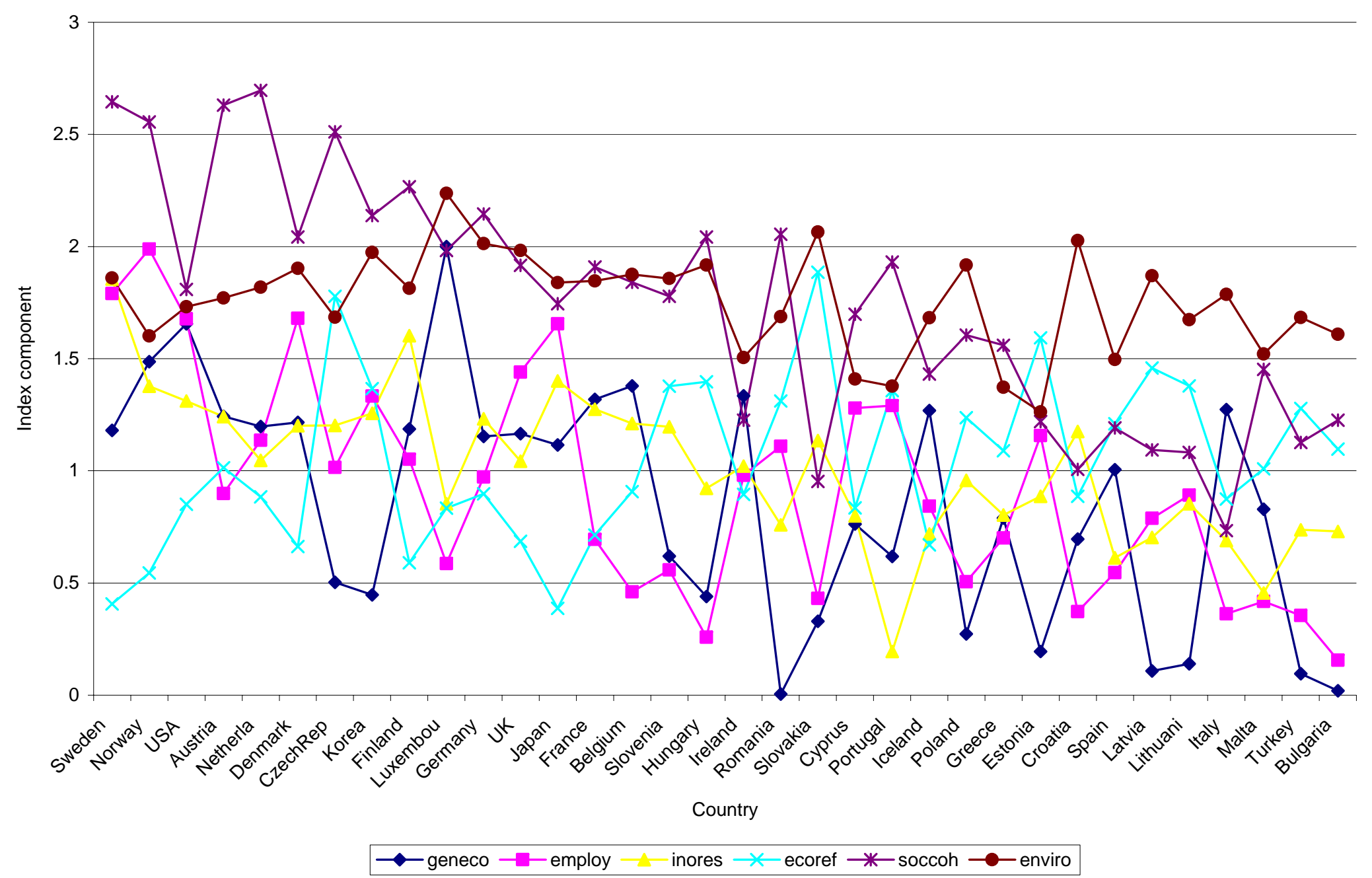


Figure 4. Lisbon Development Strategy Indices by country group.

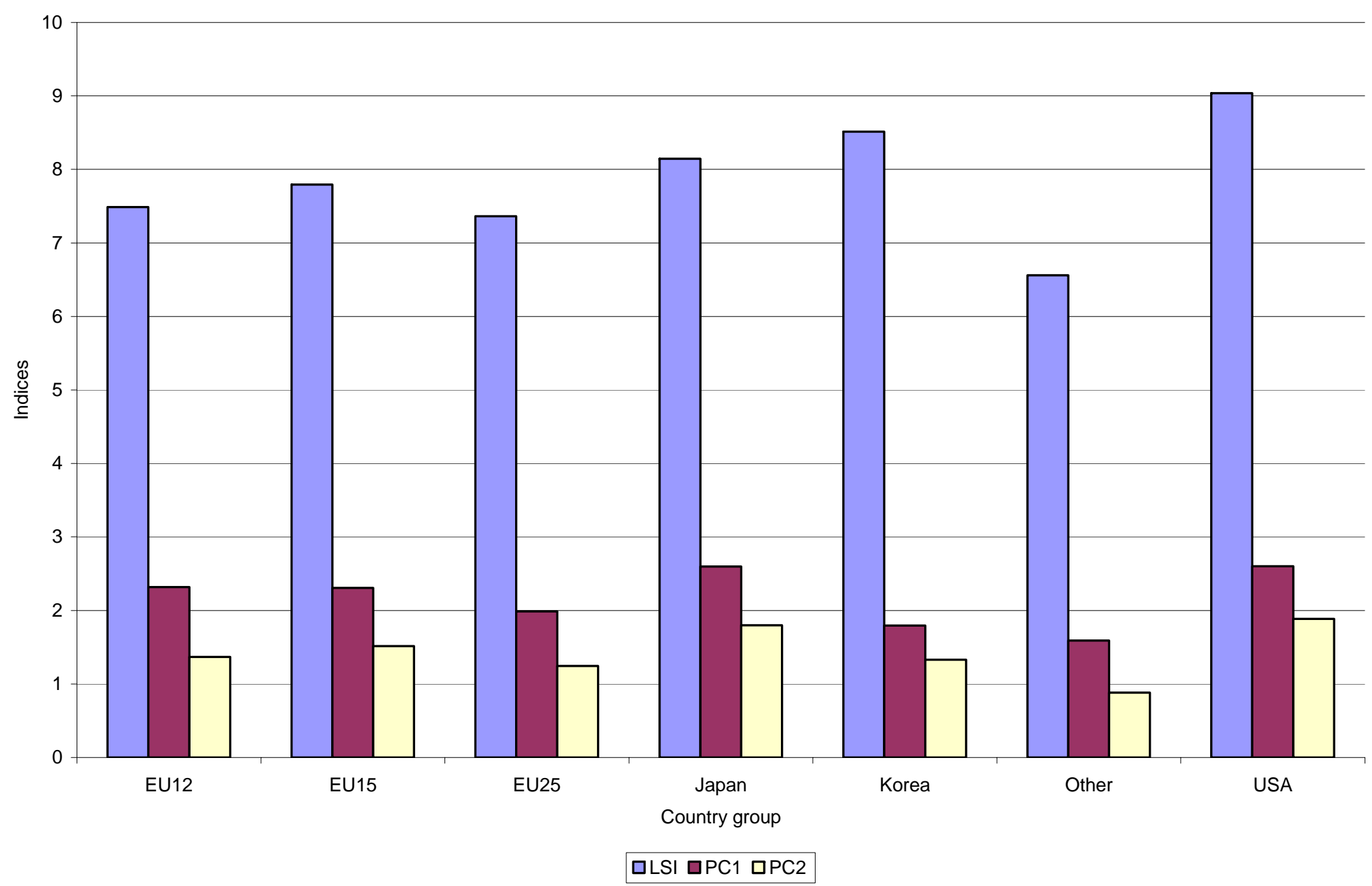


Figure 5. Development of Lisbon Strategy Indices over time.

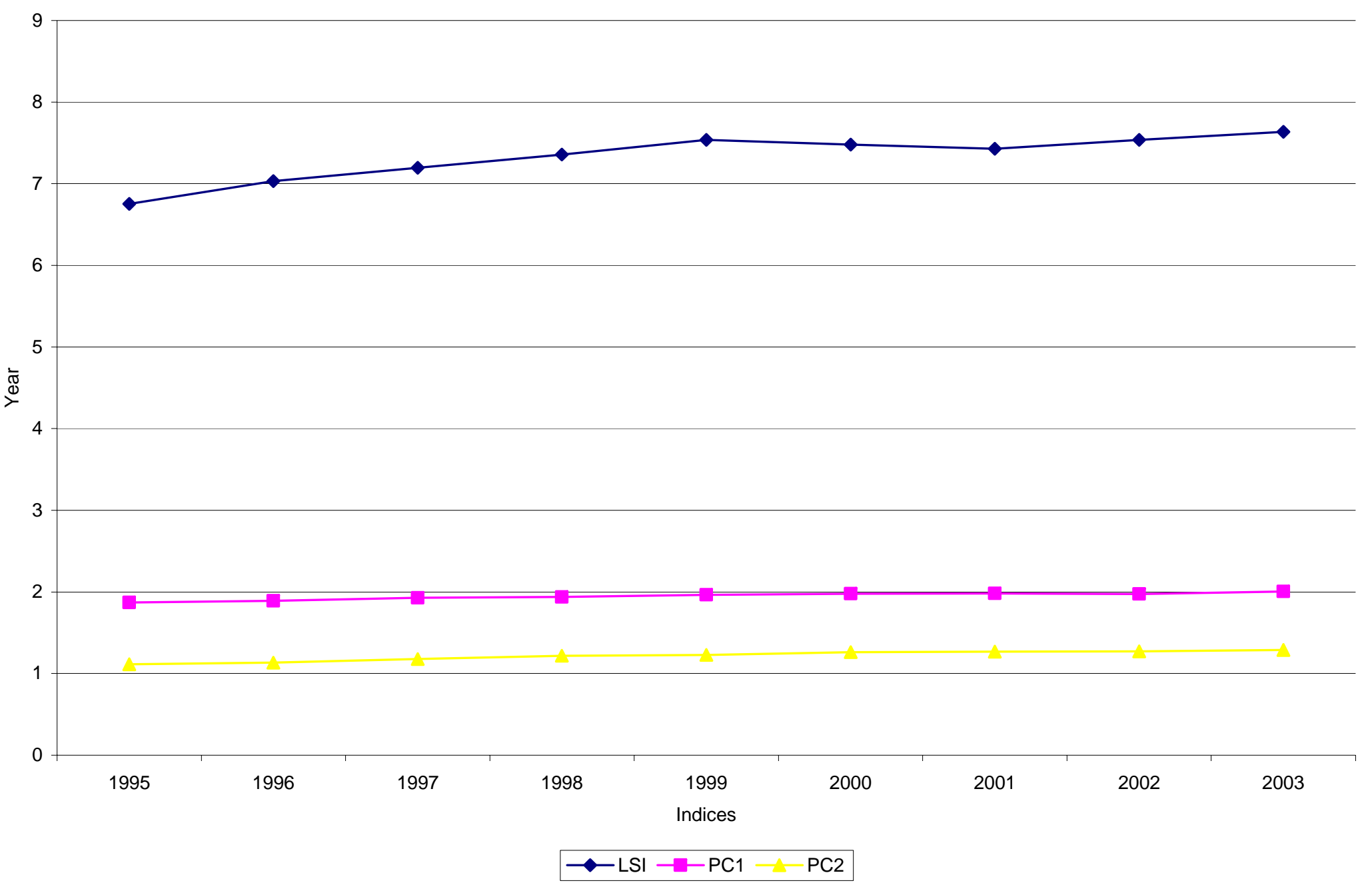

